\title{
The Supply and Use of Broadband in Rural Australia: An Explanatory Case Study of the Western Downs Region
}

\author{
Michael Lane \\ School of Management and Enterprise \\ University of Southern Queensland \\ Michael.Lane@usq.edu.au
}

\section{Sanjib Tiwari}

School of Management and Enterprise

University of Southern Queensland

\author{
Khorshed Alam \\ School of Commerce \\ University of Southern Queensland
}

\section{Abstract}

This research seeks to provide an understanding of broadband infrastructure supply and its relationship with household broadband use and satisfaction in rural Australia through an explanatory case study of the Western Downs Region (WDR). The Broadband Ecosystem provided a comprehensive framework for examining broadband infrastructure supply and household use and satisfaction with broadband services. Publicly available data was used to map the coverage of broadband access technologies in WDR. A large scale survey assessed household use and satisfaction with broadband services available in WDR. Our findings indicate that rural regions such as WDR are highly reliant on wireless broadband which is more variable in reliability and less affordable comparative to wired broadband. Our findings also indicate that household dissatisfaction with wireless broadband services is particularly evident in remote and outer regional areas. This suggests that the lack of reliable and affordable wireless broadband services with adequate data quotas are a real barrier to rural communities such as the WDR actively participating in a digital future. This study provided a number of important contributions. The broadband ecosystem provided a comprehensive framework for understanding the complex problem of broadband access in rural Australia by analysing two units of analysis, broadband infrastructure (supply) and broadband use and satisfaction (demand). Broadband infrastructure is an important and under-researched area in information systems. Future government policy needs to ensure that access to reliable and high speed broadband services is part of its universal service obligation so that the current shortcomings in broadband infrastructure in rural Australia will be prioritised and addressed. We believe this will require a commitment from future Governments to facilitate both public and private investment in broadband infrastructure in rural Australia.

Keywords: Broadband infrastructure; broadband services; rural Australia; technology use and satisfaction

\section{Introduction}

The main objective of this paper is to provide a detailed understanding of the supply, use, and satisfaction with broadband services in rural Australia through an in-depth case study of the Western Downs Region. Furthermore, this paper seeks to show that the supply of broadband infrastructure in terms of availability, speed and reliability in rural Australia influences household use and satisfaction with broadband services in rural Australia.

Broadband access has become increasingly critical for day-to-day life and business activities. Broadband is now widely considered to be one of the key enablers and drivers for social and economic growth (Budde 2014; Hudson 2013; Touré 2014). Time-series analyses of Australian Bureau of Statistics (ABS) data shows that internet subscriptions in Australia overall have increased substantially from $60 \%$ of households in $2005^{-6}$ to $86 \%$ of households in 2014-15, 
although household adoption and use of the internet by rural Australia is still lagging behind urban Australia (ABS 2016). Rural Australia could be directly affected if many rural communities are excluded from the potential benefits of accessing and utilising broadband infrastructure as a universal service. Inadequate broadband infrastructure and lower levels of services in rural areas are ongoing problems (Alam \& Imran 2015; Bandias \& Ram Vemuri 2005; Park et al. 2015). According to the 2014-15 Regional Telecommunications Review (RTR), individuals and businesses in rural communities have limited options in choosing a broadband provider; they typically have lower internet connection speeds, smaller data quotas, limited mobile broadband availability and generally higher prices compared to their urban counterparts (RTIRC 2015). This ultimately impacts on effective use of digital services in rural Australia. While numerous previous studies have been conducted on adoption and use of broadband these have tended to focus on impacts at the macro level or national level such as socio-economic development, developing broadband diffusion strategies and policy, and providing some technical solutions for rural broadband (Islam, Selvadurai \& Town 2008; Middleton \& Chang 2008; Stern et al. 2004). There has been a lack of in-depth empirical studies aimed specifically at rural Australia that have examined the broadband ecosystem (Kelly \& Rossotto 2012) by investigating supply, demand/use and satisfaction at the micro level (Hill, Burgan \& Troshani 2011; Hollifield \& Donnermeyer 2003). Although the RTR study shows that there is a lack of broadband infrastructure in Australian rural communities, a significant gap in the literature exists in terms of a detailed study of the relationship between supply of broadband infrastructure and household use and satisfaction with broadband services in rural Australia (Whitacre, Strover \& Gallardo 2015). In general, it is argued there has been a lack of empirical studies on digital infrastructure, including broadband infrastructure. Tilson, Lyytinen and Sørensen (2010) refer to digital infrastructure research as the orphan of information systems research and an important but under-researched area.

Therefore, the aim of this research is to investigate the problems associated with broadband access by focusing on supply of broadband infrastructure and household use and satisfaction with broadband services in rural Australia in order to provide a more complete picture and understanding of the problem. The use of broadband is based on its availability and capability to meet requirements of the users-in other words, highly dependent upon both the supply of, and the demand for, that technology (Middleton \& Chang 2008). In this paper some of the key results of an in-depth case study of the broadband infrastructure (supply) and Household use and satisfaction with broadband services in rural Australia-specifically the Western Downs Region-are presented.

The paper is structured as follows. First, we present the theoretical and conceptual framework - the broadband ecosystem - which provides the context and, subsequently, guided the data collection and analysis in this study. Then we provide a background to adoption and use of broadband in Australia and the digital divide that exists between urban and rural Australia due to the lack of reliable and affordable broadband infrastructure in rural Australia. The methodological approach used in this study is described and justified. Thereafter, we provide a snapshot of the current broadband infrastructure (supply-side) available in the Western Downs Region. This helps to more fully explain some of the key findings regarding household use (demand-side) and satisfaction with broadband services in the Western Downs Region. The results of the data analysis presented in this paper sought to address following research questions:

RQ1: What broadband access technologies are available and in what locations in the WDR?

RQ2: What is the extent of use of broadband services by households in the WDR?

RQ3: What is the extent of satisfaction of households with the broadband services available in the WDR?

Subsequently, some conclusions and implications regarding theory and practice are provided, drawing on the key findings reported in this paper. 


\section{Background Literature for Study}

\subsection{Broadband Ecosystem Model}

The World Bank Ecosystem Framework for deployment and adoption of broadband provided the theoretical and conceptual framework for understanding the supply of broadband infrastructure, demand (adoption) and use of broadband (Cohen \& Levintbal 1990; World Bank 2012) (see Figure 1 Broadband Ecosystem adapted from World Bank). The broadband ecosystem includes the broadband networks, broadband-compatible devices, content and applications (FCC 2010). The broadband ecosystem is characterised by wired and wireless broadband network services and computing devices for accessing broadband and a key range of stakeholders, namely consumers, business and government which, in turn, influence the adoption and use of applications and content. In this research we focus on the relationship between the broadband infrastructure - networks that deliver broadband as a service - and the household use and satisfaction with broadband in rural Australia. In other words, the supply and use elements of the broadband ecosystem. The broadband ecosystem framework has been adapted to the context of this study by including satisfaction with broadband services as a variable that influences use. The overall impact of the broadband ecosystem is framed within rural communities.

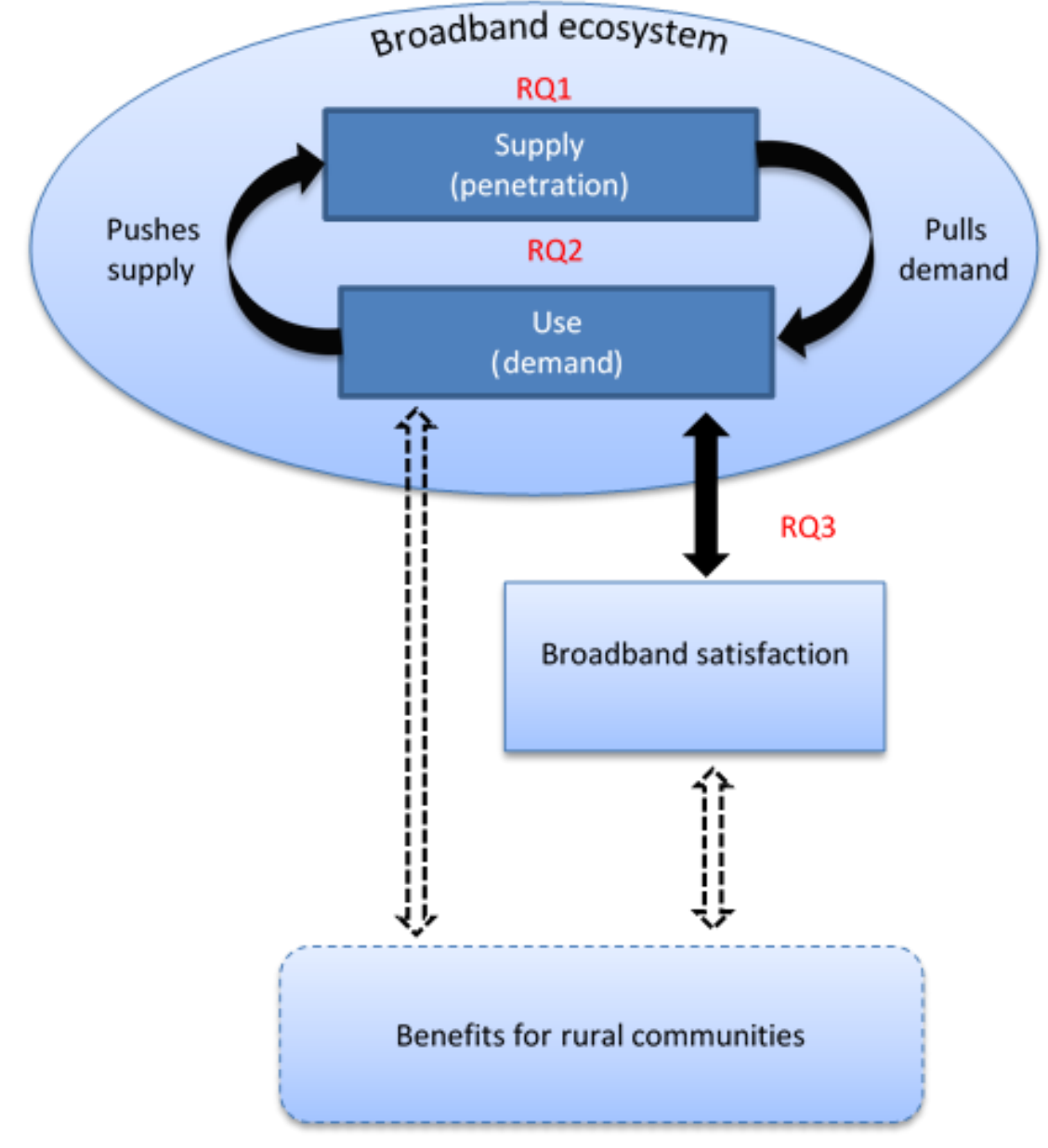

Figure 1: Broadband Ecosystem (Source: adapted from World Bank Broadband Tool Kit 2012; (Kelly \& Rossotto 2012))

Broadband internet can be represented as an ecosystem consisting of supply and demand components which are equally important to the successful expansion and delivery of broadband infrastructure and services (Kelly \& Rossotto 2012). The supply side is concerned with the push-the building and delivering broadband network infrastructure which encourages increased demand for broadband services. The demand side is concerned with 
using the available infrastructure to access digital services which ultimately encourages the push of latest broadband access technologies. There is evidence that providing faster, cheaper broadband internet services with increased data quotas increases customer satisfaction and the likelihood of more engagement with broadband access technologies. Higher infrastructure quality is expected to lead to better broadband Internet performances and higher user satisfaction and use, leading to positive benefits for individuals and rural communities. This should result in greater use of broadband and ensuing benefits in various sectors, including education, health, communication, work and other digital services; and also drive demand for higher speed broadband services (Kerpez et al. 2014; Seymour \& Naidoo 2013). The use of broadband has been demonstrated to have a positive impact on regional, state and national GDP in countries which have embraced broadband and have the digital literacy to utilise broadband to drive technology led innovation (Gruber, Hätönen \& Koutroumpis 2014; Whitacre, Gallardo \& Strover 2014). When supply, demand and use are co-ordinated, the benefits of broadband in rural communities will be significant-with improved satisfaction with broadband services resulting in significant realised benefits in terms of economic, human and social capital.

\subsection{Availability of Broadband in Rural Australia}

The supply of broadband in rural areas of developed countries has been much lower compared to urban areas (ABS 2013a; Dobson, Jackson \& Gengatharen 2013; Dwivedi, Alsudairi \& Irani 2010; Grubesic 2012; Kawade \& Nekovee 2012; Prieger 2013; Rajabiun \& Middleton 2013). A combination of poor telecommunications infrastructure coverage, low population density, inadequate regulation, and a focus by telecommunications companies on high-cost technologies designed for urban markets makes internet connectivity in many rural areas a complex and costly proposition (Arai, Naganuma \& Satake 2012; Grubesic 2012; Hill, Troshani \& Burgan 2014; Kawade \& Nekovee 2012). Due to inadequate information and communication infrastructure and facilities in rural and remote areas, the digital divide between rural communities and urban communities is not improving and could be widening (Park et al. 2015; Willis \& Tranter 2006).

Table 1 highlights that wireless broadband access technology is a finite shared broadband service which is highly susceptible to interference in contrast to wired broadband, in particular, fibre optic broadband which has abundant capacity and is highly reliable (Lehr \& Chapin 2009). This is particularly pertinent for rural Australia, where many smaller towns have limited or no access to wired broadband such as ADSL/ADSL2+ and are highly reliant on wireless broadband, in particular, mobile broadband.

\begin{tabular}{|l|l|l|}
\hline Network capability & $\begin{array}{l}\text { Wired broadband } \\
\text { networks }\end{array}$ & $\begin{array}{l}\text { Wireless broadband } \\
\text { networks }\end{array}$ \\
\hline Capacity & Abundant & Scarce \\
\hline Topology & Point-to-point & Broadcast \\
\hline Reliability & Reliable & Unreliable \\
\hline Mobility & Fixed & Mobile \\
\hline Layering & Effective & Inefficient \\
\hline
\end{tabular}

Legend: Wired Broadband (Fibre optic, ADSL), Wireless Broadband (3G/4G Mobile networks, Satellite Broadband)

Table 1: Key persistent differences in Wired Broadband versus Wireless Broadband (Source: adapted from Lehr \& Chaplin 2009)

Typically, rural Australia lags behind urban Australia in terms of broadband infrastructure which is often highly variable in terms of speed, reliability, and is often under serviced or not serviced in large parts of rural Australia in comparison to urban Australia (see Table 2) (Dobson, Jackson \& Gengatharen 2013; Hill, Burgan \& Troshani 2011; Hill, Troshani \& Burgan 2014; Middleton \& Park 2014; RTIRC 2015). 


\begin{tabular}{|c|c|c|c|c|c|}
\hline \multirow{2}{*}{$\begin{array}{l}\text { Broadband } \\
\text { Access } \\
\text { Technology }\end{array}$} & \multirow{2}{*}{$\begin{array}{l}\text { Download } \\
\text { Speed }\end{array}$} & \multirow{2}{*}{$\begin{array}{l}\text { Upload } \\
\text { Speed }\end{array}$} & \multicolumn{3}{|l|}{ Availability } \\
\hline & & & $\begin{array}{l}\text { Inner } \\
\text { regional }\end{array}$ & $\begin{array}{l}\text { Outer } \\
\text { Regional }\end{array}$ & Remote \\
\hline ADSL1 & $8 \mathrm{Mbps}$ & $384 \mathrm{Kbps}$ & Available & Available & $\begin{array}{l}\text { Limited } \\
\text { Availability }\end{array}$ \\
\hline ADSL2+ & $20 \mathrm{Mbps}$ & $820 \mathrm{Kbps}$ & Available & $\begin{array}{l}\text { Limited } \\
\text { Availability }\end{array}$ & Not Available \\
\hline Cable (HSD) & $100 \mathrm{Mbps}$ & $2 \mathrm{Mbps}$ & $\begin{array}{l}\text { Limited } \\
\text { Availability }\end{array}$ & Not available & Not Available \\
\hline NBN Fibre & $100 \mathrm{Mbps}$ & $40 \mathrm{Mbps}$ & $\begin{array}{l}\text { Limited } \\
\text { Availability }\end{array}$ & Not available & Not Available \\
\hline $3 \mathrm{G}$ & $7.2 \mathrm{Mbps}$ & $2 \mathrm{Mbps}$ & Available & Available & Available \\
\hline 3G HSPA+ & $42 \mathrm{Mbps}$ & $22 \mathrm{Mbps}$ & Available & $\begin{array}{l}\text { Limited } \\
\text { Availability }\end{array}$ & $\begin{array}{l}\text { Limited } \\
\text { Available }\end{array}$ \\
\hline 4G- LTE & $150 \mathrm{Mbps}$ & $50 \mathrm{Mbps}$ & $\begin{array}{l}\text { Limited } \\
\text { Availability }\end{array}$ & $\begin{array}{l}\text { Limited } \\
\text { Availability }\end{array}$ & Not Available \\
\hline $\begin{array}{l}\text { 4G- LTE } \\
\text { Advanced }\end{array}$ & $300 \mathrm{Mbps}$ & 150 Mbps & $\begin{array}{l}\text { Limited } \\
\text { Availability }\end{array}$ & $\begin{array}{l}\text { Limited } \\
\text { Availability }\end{array}$ & Not Available \\
\hline $\begin{array}{l}\text { NBN Fixed } \\
\text { Wireless }\end{array}$ & $50 \mathrm{Mbps}$ & $20 \mathrm{Mbps}$ & $\begin{array}{l}\text { Limited } \\
\text { Availability }\end{array}$ & $\begin{array}{l}\text { Limited } \\
\text { Availability }\end{array}$ & Not Available \\
\hline $\begin{array}{l}\text { NBN Satellite } \\
\text { Wireless }\end{array}$ & $25 \mathrm{Mbps}$ & $1 \mathrm{Mbps}$ & $\begin{array}{l}\text { Limited } \\
\text { Availability }\end{array}$ & $\begin{array}{l}\text { Limited } \\
\text { Availability }\end{array}$ & Available \\
\hline
\end{tabular}

Table 2: Download and Upload Speeds for Broadband Access Technologies in Australia (Source: this research)

Table 3 suggests that the growth in mobile broadband presents a dilemma for rural Australia as the exponential growth in demand for data is outstripping the capacity of the current mobile network infrastructure available in much of rural Australia. This further exacerbates problems faced in rural communities because of the availability of broadband access technologies. In particular, fixed line broadband access technologies - which provide users with much larger and cheaper data quotas comparatively than mobile broadband technologies such as $3 \mathrm{G} / 4 \mathrm{G}$ and satellite broadband-are limited to the larger towns in rural Australia (as evidenced in Table 2). Further investigation of the www.rfnsa.com.au and www.adsl2exchanges.com.au websites revealed a similar pattern of wired and wireless broadband coverage for a number of other rural regions in Australia (See our detailed analysis presented in the Results and Discussion section).

The Australian Government and key policymakers are well aware that rural communities have a demand and requirement for high quality broadband and telecommunication services (Middleton \& Park 2014). The Australian Federal Government has also held a number of consultations with businesses and the general public and received many recommendations to improve broadband availability and access. As a result, many policies have been developed to invest in more broadband infrastructure in rural communities. However, to date, none of these policies have been fully implemented or have lagged in the roll out-the NBN being a good case in point. Hence, major efforts to overcome the digital divide that exists between urban and rural communities have so far been unsuccessful (Given 2008; Middleton \& Park 2014).

More recently, starting from a very low base in 2006, we have seen an exponential increase in the adoption of mobile broadband services which contributed significantly to the overall adoption of broadband services across Australia. Figure 2 shows how mobile broadband services have overtaken fixed line ADSL services since 2010; while dial-up narrowband access has become almost negligible after being accountable for almost $50 \%$ of internet access technologies back in 2006 (ABS 2013b, 2015). Figure 2: Number of internet subscribers by Internet access connection technology (Source: (ABS 2015) 


\section{Proportion of Internet subscribers by connection type, for ISPs with more than 1,000 subscribers}

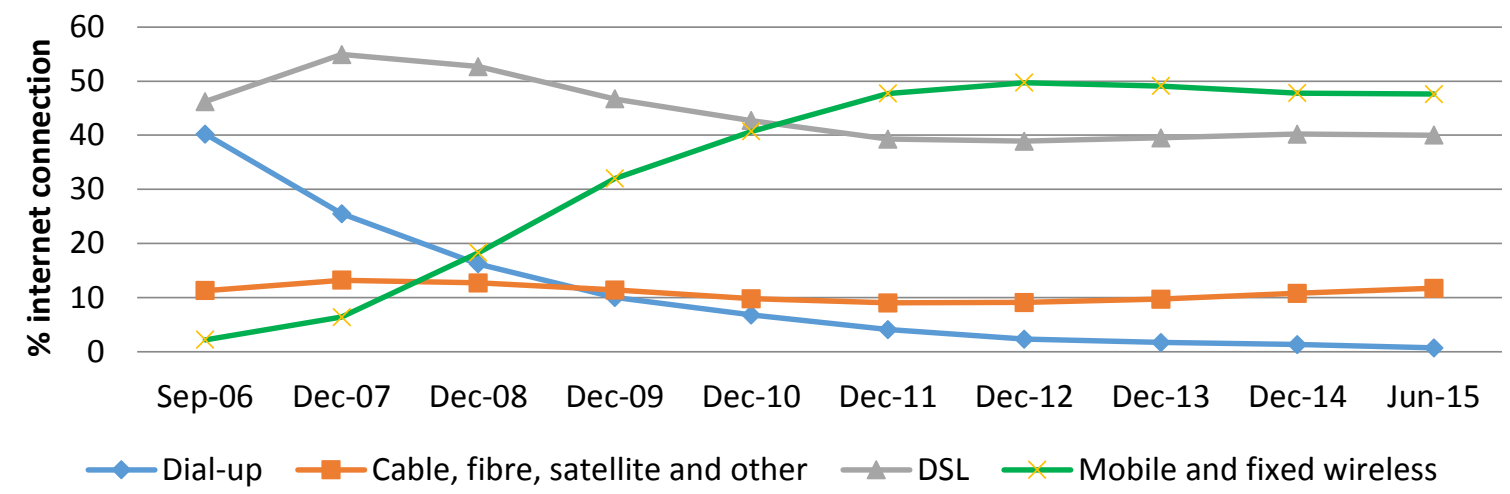

Figure 2: Number of internet subscribers by Internet access connection technology (Source: (ABS 2015)

\begin{tabular}{|l|r|r|r|r|r|r|r|}
\hline & Jun-12 & Dec-12 & Jun-13 & Dec-13 & Jun-14 & Dec-14 & Jun-15 \\
\cline { 2 - 9 } & TB & TB & TB & TB & TB & TB & TB \\
\hline Broadband & & & & & & & \\
\hline Fixed line (b) & 389130 & 526472 & 629964 & 823,421 & 963,429 & $1,112,379$ & $1,349,975$ \\
\hline Wireless (c) & 25301 & 28196 & 27232 & 37,426 & 32,731 & 34,339 & 38,673 \\
\hline Total broadband & 414431 & 554668 & 657196 & 860,847 & 996,160 & $1,146,718$ & $1,388,648$ \\
\hline $\begin{array}{l}\text { Total volume of } \\
\text { data downloaded } \\
\text { (d) }\end{array}$ & $\mathbf{4 1 4} 537$ & $\mathbf{5 5 4} 771$ & $\mathbf{6 5 7 2 6 2}$ & & & & \\
\hline \\
$\begin{array}{l}\text { (a) Data reported for the three month period prior to the reference date. } \\
\text { (b) Fixed line includes DSL, cable, fibre and other fixed line broadband. } \\
\text { (c) Wireless includes satellite, fixed wireless, mobile wireless via a datacard, dongle, USB modem or tablet SIM } \\
\text { card and other wireless broadband. Excludes data downloaded via mobile handsets which is reported in the } \\
\text { mobile handset chapter. }\end{array}$ \\
(d) Dial-up volume is not shown separately, but is included in the total. (ABS 2015) \\
\hline
\end{tabular}

Table 3: Volume of data downloaded by type of access connection (a), ISPs more than 1,ooo subscribers (Source: ABS 2015)

However, this rapid adoption of mobile broadband services does not tell the true story of the relationship between the data explosion and use of different broadband access technologies (see Table 3). Currently as a broadband access technology, mobile broadband is prohibitive in terms of speed and cost of data usage comparative to wired broadband access technologies such ADSL1/ADSL2+ and Fibre to the Home or Node (Chaleyer-Kynaston 2012; Wallsten \& Mallahan 2010). A comparison of mobile broadband and ADSL services based on cost and data quotas is provided in Appendix 1. It also must be noted with reference to Table 3 that mobile phone subscriptions, which are usually individual subscriptions, cannot be equally compared to ADSL broadband subscriptions - which are usually household subscriptions. Moreover, data quotas are currently quite restrictive for mobile phones compared to data quotas available for ADSL broadband services. Hence, growth in data usage has predominately been with fixed line broadband services, although this is likely to change over time as mobile data services decrease in cost while at the same time increasing substantially in terms of data download/upload speeds with the roll out of $4 \mathrm{G}$ mobile networks. 
Table 3 further highlights some critical differences between wired broadband and wireless broadband in terms of data usage over the period from June 2012 through to June 2015 referencing ABS national data. The rapid improvements in wireless broadband access technology cannot alone meet exponential growth in demand for data that will occur in the future. Despite the rapid rise of mobile broadband access technologies this has tended to disadvantage rural Australia. The rural Australia has a high reliance on mobile broadband networks for broadband services particular in remote and outer regional areas and the inherent shortcomings of mobile broadband as a wireless broadband access technology are notable as highlighted in Table 1. There is also a reluctance of mobile phone operators to invest in upgrading mobile broadband infrastructure in rural Australia given the lower return on investment because of low population densities.

In the next section we provide an overview of the case study location - the Western Downs Region-where we examined the broadband supply (infrastructure) and the household demand (adoption), use and satisfaction with broadband services.

\subsection{Case Study Site: Western Downs Region (WDR)}

The WDR is located in South-east Queensland (SE Qld) 200 kilometres north west of Brisbane, the capital city of Queensland, Australia. The economy of the WDR has continued to grow at an extensive pace in the last five years to 2014/15, where the annual growth rate of $6.3 \%$ is significantly higher than the annual overall growth rate for the State of Queensland (2.5\%) over the same period of time (WDRC 2015). Western Downs Regional Council (WDRC) is the 20th largest council in terms of area in Queensland. The Western Downs has six main towns, namely, Dalby, Chinchilla, Jandowae, Miles, Tara and Wandoan-with another 14 smaller towns and villages scattered throughout the region.
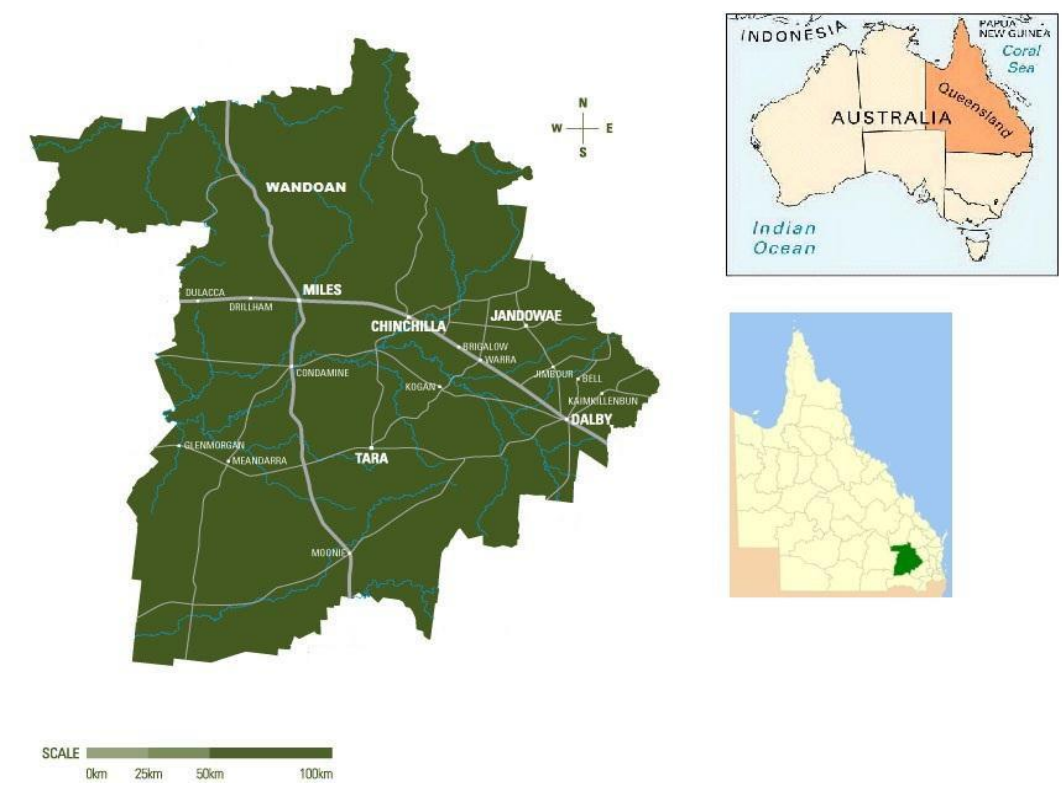

Figure 3: Showing study area - Western Downs Region, Queensland, Australia (Source: Advance Western Downs 2015, Davis n.d., Western Downs Region Wikipedia 2015)

The WDR is rich in coal and natural gas reserves which underpin the power generation industry for SE Qld. The region is also well-known as a rich agricultural area for broad acre and intensive cropping, dairy products and meat production (WDR 2015). However, the region still experiences poor telecommunication services and infrastructure (especially mobile) in many locations, with many black spots and poor coverage for both voice and data (internet) communications.

The Australian Standard Geographical Classification (ASGC) defines the relative remoteness of rural communities in Australia (ABS 2014). Since this study is examining a rural region of Australia, we used the ASGC classification to classify rural communities (towns) in the WDR 
as one of three: (1) Inner Regional Australia, (2) Outer Regional Australia and (3) Remote Australia (See Table 5).

\section{Research Method and Approach}

This research used an explanatory case study approach to evaluate the supply, demand and use of broadband internet in rural communities in the Western Downs Region (Yin 2014; Stake 1995). An explanatory case study guided by the Broadband Ecosystem framework (Kelly \& Rossotto 2012) allowed us to gain an in-depth of understanding of the phenomena of interest, the relationship of broadband infrastructure supply with household use and satisfaction with broadband services in rural Australia. The two units of analysis in this study are (1) broadband infrastructure supply in rural communities, and (2) household use of broadband services in rural communities of WDR. Multiple sources of quantitative data obtained for these two units of analysis allowed the researchers to capture a rich picture and deep understanding of the phenomena of interest in the explanatory case study of WDR.

To determine and assess broadband infrastructure available in the WDR (to answer Research Question 1) archival data from the Radio Frequency National Site Archive (RFNSA) (www.rfnsa.com.au) (RFNSA 2016) and publicly contributed data from the social media website www.adsl2exchanges.com.au (ADSL2-Exchanges 2015) were used. This allowed us to construct Table 5 which provides an overview of the wired and wireless broadband infrastructure availability across the 20 towns in the WDR. We also constructed similar tables for rural regions in other parts of rural Australia to provide a comparison of the available broadband infrastructure. This study also conducted mobile broadband speed tests to check the reliability and availability of services using the OpenSignal mobile app (www.opensignal.com) (OpenSignal 2014) for the three mobile network services (Telstra, Optus and Vodafone) providers in the WDR.

This research also conducted a large scale survey of households in the WDR during 2014 to collect quantitative data about household adoption and use of broadband internet. The survey instrument was developed from a number of previous studies on broadband technology adoption and use which have used instruments proven to be valid and reliable (Straub, Boudreau \& Gefen 2004). A number of key definitions were provided in the survey, including the definition of broadband provided by OECD and NBN (NBN 2014; OECD 2014) so that survey participants had a clear idea what was meant by the term 'broadband'. The survey instrument was pre tested with a number of academics with extensive experience in survey research design. The survey was then piloted with a number of households before the main survey data collection was undertaken. The survey instrument is available on request from the authors.

The survey package was delivered in person to randomly selected households using a stratified sampling method to ensure that 1500 surveys were distributed to a sample representative of the population distribution of the towns and localities in the WDR. A total of 301 usable survey responses were obtained (see Table 4). A response rate of $20 \%$ was achieved, which is comparable to similar previous studies of broadband adoption and use by households (Brown \& Venkatesh 2005; Dwivedi, Alsudairi \& Irani 2010; Dwivedi, Choudrie \& Brinkman 2006). Table 4 shows the geographical distribution of household survey responses across the WDR. 


\begin{tabular}{|l|r|r|l|}
\hline \multicolumn{1}{|c|}{ Location in WDR } & $\begin{array}{c}\text { Household } \\
\text { Responses }\end{array}$ & Percentage & $\begin{array}{c}\text { Combined district } \\
\text { percentage }\end{array}$ \\
\hline Live in Dalby & 125 & $42 \%$ & Dalby district combined $49 \%$ \\
\hline Nearest to Dalby & 21 & $7 \%$ & \\
\hline Live in Chinchilla & 29 & $10 \%$ & Chinchilla district combined 13\% \\
\hline Nearest to Chinchilla & 10 & $3 \%$ & \\
\hline Live in Tara & 10 & $3 \%$ & Tara district combined 7\% \\
\hline Nearest to Tara & 12 & $4 \%$ & \\
\hline Live in Miles & 13 & $4 \%$ & Miles district combined 8\% \\
\hline Nearest to Miles & 10 & $3 \%$ & \\
\hline Live in Wandoan & 14 & $5 \%$ & Wandoan district combined 6\% \\
\hline Nearest to Wandoan & 4 & $1 \%$ & \\
\hline Live in Jandowae & 15 & $5 \%$ & Jandowae district combined $7 \%$ \\
\hline Nearest to Jandowae & 7 & $2 \%$ & \\
\hline Other place (please specify) & 31 & $10 \%$ & Other places in WDR 10\% \\
\hline & 301 & $100 \%$ & \\
\hline
\end{tabular}

Table 4: Geographical distribution of respondent households in WDR survey

Proportionately, the respondent households are reasonably representative of the population distribution across the towns and surrounding districts in the study area of the WDR.

The survey data was analysed using the statistical data analysis software SPSS. The interpretation of the results of the survey data in relation to research questions 2 and 3 was also informed by the understanding of the available broadband infrastructure gained from the audit of broadband infrastructure in the WDR which was addressed by research question 1.

\section{Results and Discussion}

First we present our findings for RQ1: an assessment of the supply of broadband services in the WDR. Then we present some key findings from the household broadband adoption and use survey which addressed the main aims of RQ2: the use of broadband by households. The main aim of RQ3 was to determine the level of household satisfaction with the broadband services available to them in the WDR.

\subsection{Access and availability of broadband infrastructure}

Table 5 provides an overview of broadband infrastructure availability in the WDR. 


\begin{tabular}{|c|c|c|c|c|c|c|c|c|}
\hline & Pop & PSTN & ADSL1 & ADSL2+ & $\begin{array}{l}\text { Fibre } \\
\text { optic } \\
\text { backbone }\end{array}$ & 3G & 4G & ASGC \\
\hline Dalby & 16000 & $\mathbf{Y}$ & $\mathbf{Y}\left({ }^{*} \mathbf{T}\right)$ & $\mathbf{Y}(* \pm)$ & Y (C) & $\begin{array}{c}\mathbf{Y} \\
\text { (All) }\end{array}$ & $\begin{array}{c}\mathbf{Y} \\
\text { (All) }\end{array}$ & $\begin{array}{c}\text { Inner } \\
\text { Regional }\end{array}$ \\
\hline Chinchilla & 7200 & $\mathbf{Y}$ & $Y(T)$ & $Y(T)$ & $Y(C)$ & $\begin{array}{c}\mathbf{Y} \\
\text { (All) }\end{array}$ & $\begin{array}{c}\mathbf{Y} \\
\text { (All) }\end{array}$ & $\begin{array}{c}\text { Outer } \\
\text { Regional }\end{array}$ \\
\hline Miles & 1450 & $\mathbf{Y}$ & $Y(T)$ & $Y(T)$ & $Y(C)$ & $\begin{array}{c}\mathbf{Y} \\
\text { (All) }\end{array}$ & $\begin{array}{c}Y \\
\text { (All) }\end{array}$ & $\begin{array}{c}\text { Outer } \\
\text { Regional }\end{array}$ \\
\hline Tara & 1100 & $\mathbf{Y}$ & $Y(T)$ & $Y( \pm T)$ & $\mathbf{N}$ & $\begin{array}{c}Y \\
(T)\end{array}$ & $\mathbf{N}$ & $\begin{array}{c}\text { Outer } \\
\text { Regional }\end{array}$ \\
\hline Jandowae & 1000 & $\mathbf{Y}$ & $Y(T)$ & $Y(T)$ & $\mathbf{N}$ & $\begin{array}{c}\mathbf{Y} \\
\text { (TO) }\end{array}$ & $\begin{array}{c}\mathbf{Y} \\
\text { (TO) }\end{array}$ & $\begin{array}{c}\text { Outer } \\
\text { Regional }\end{array}$ \\
\hline Wandoan & 400 & $\mathbf{Y}$ & $Y(T)$ & $Y(T)$ & $\mathbf{N}$ & $\begin{array}{c}Y \\
\text { (TO) }\end{array}$ & $\mathbf{Y}(\mathbf{T})$ & Remote \\
\hline Bell & 300 & $\mathbf{Y}$ & $Y(T)$ & $\begin{array}{l}\text { Proposed } \\
\text { (T) }\end{array}$ & $\mathbf{N}$ & $\begin{array}{c}\mathbf{Y} \\
\text { (TO) }\end{array}$ & $\mathbf{Y}(\mathbf{O})$ & $\begin{array}{c}\text { Outer } \\
\text { Regional }\end{array}$ \\
\hline Meandarra & 250 & $\mathbf{Y}$ & $\mathbf{Y}(\mathbf{T})$ & $Y(T)$ & $\mathbf{N}$ & $Y(T)$ & $Y(T)$ & Remote \\
\hline Condamine & 135 & $\mathbf{Y}$ & $\mathbf{Y}(\mathrm{T})$ & $Y(T)$ & $\mathbf{N}$ & $\begin{array}{c}Y \\
(T)\end{array}$ & $\mathbf{N}$ & $\begin{array}{c}\text { Outer } \\
\text { Regional }\end{array}$ \\
\hline Dulacca & 120 & $\mathbf{Y}$ & $\mathbf{N}( \pm T)$ & $\begin{array}{l}\text { Proposed } \\
\text { (T) }\end{array}$ & $\mathbf{N}$ & $\begin{array}{c}\mathbf{Y} \\
(\mathbf{O})\end{array}$ & $\mathbf{Y}(\mathbf{O})$ & Remote \\
\hline Warra & 120 & $\mathbf{Y}$ & $\mathbf{N}( \pm \mathbf{T})$ & $\begin{array}{l}\text { Proposed } \\
\text { (T) }\end{array}$ & $\mathbf{N}$ & $\begin{array}{c}\mathbf{Y} \\
\text { (TO) }\end{array}$ & Y(TO) & $\begin{array}{c}\text { Outer } \\
\text { Regional }\end{array}$ \\
\hline Kaimkillenbun & 100 & $\mathbf{Y}$ & $\mathbf{N}( \pm T)$ & $\begin{array}{l}\text { Proposed } \\
\text { (T) }\end{array}$ & $\mathbf{N}$ & $\mathbf{N}^{\wedge}$ & $\mathbf{N}$ & $\begin{array}{c}\text { Outer } \\
\text { Regional }\end{array}$ \\
\hline Drillham & 70 & $\mathbf{Y}$ & $\mathbf{N}$ & $\mathbf{N}$ & $\mathbf{N}$ & $\mathbf{Y}(\mathrm{T})$ & $\mathbf{Y}(\mathbf{T})$ & $\begin{array}{c}\text { Outer } \\
\text { Regional }\end{array}$ \\
\hline Brigalow & 40 & $\mathbf{Y}$ & $\mathbf{N}( \pm \mathbf{T})$ & $\begin{array}{l}\text { Proposed } \\
\text { (T) }\end{array}$ & $\mathbf{N}$ & $\mathbf{N}^{\wedge}$ & $\mathbf{N}$ & $\begin{array}{c}\text { Outer } \\
\text { Regional }\end{array}$ \\
\hline Kogan & 40 & $\mathbf{Y}$ & $\mathbf{N}( \pm T)$ & $\begin{array}{l}\text { Proposed } \\
\text { (T) }\end{array}$ & $\mathbf{N}$ & $\mathbf{Y}(\mathrm{T})$ & $\mathbf{Y}(\mathbf{T})$ & $\begin{array}{c}\text { Outer } \\
\text { Regional }\end{array}$ \\
\hline Moonie & 40 & $\mathbf{Y}$ & $\mathbf{N}( \pm T)$ & $\begin{array}{l}\text { Proposed } \\
\text { (T) }\end{array}$ & $\mathbf{N}$ & $\mathbf{N}^{\wedge}$ & $\mathbf{N}$ & Remote \\
\hline Jimbour & 40 & $\mathbf{Y}$ & $\mathbf{N}( \pm \mathbf{T})$ & $\begin{array}{l}\text { Proposed } \\
\text { (T) }\end{array}$ & $\mathbf{N}$ & $\mathbf{N}^{\wedge}$ & $\mathbf{N}$ & $\begin{array}{c}\text { Outer } \\
\text { Regional }\end{array}$ \\
\hline Glenmorgan & 20 & $\mathbf{Y}$ & $\mathbf{N}( \pm \mathbf{T})$ & $\begin{array}{l}\text { Proposed } \\
\text { (T) }\end{array}$ & $\mathbf{N}$ & $\mathbf{N}^{\wedge}$ & $\mathbf{N}$ & Remote \\
\hline Macalister & 15 & $\mathbf{Y}$ & $\mathbf{N}( \pm T)$ & $\begin{array}{l}\text { Proposed } \\
\text { (T) }\end{array}$ & $\mathbf{N}$ & $\mathbf{N}^{\wedge}$ & $\mathbf{N}$ & $\begin{array}{c}\text { Outer } \\
\text { Regional }\end{array}$ \\
\hline Gulugaba & 10 & $\mathbf{Y}$ & $\mathbf{N}( \pm T)$ & $\begin{array}{l}\text { Proposed } \\
\text { (T) }\end{array}$ & $\mathbf{N}$ & $\mathbf{N}^{\wedge}$ & $\mathbf{N}$ & Remote \\
\hline
\end{tabular}

Legend $\mathrm{Y}=$ Available; $\mathrm{N}=$ Not Available; $\mathrm{N}^{\wedge}=$ Rely on signal from mobile phone tower in neighbouring town; $\mathrm{C}=$ Commerical Use Only; $\mathrm{T}=$ Telstra; $\mathrm{O}=$ Optus; V=Vodafone $\mathrm{Y}(\mathrm{All})=$ Telstra, Optus \& Vodafone; $\mathrm{TO}=$ Telstra \& Optus; TV= Telstra \& Vodafone, ${ }^{*}=$ Agile (Internode) and Chime (iiNet); $\pm=$ Telstra no ports available.

[Notes: Satellite broadband - Coverage of entire region but only available to households and businesses in remote areas with no access to alternative broadband services

Radio networks - Proprietary radio networks cover the entire region but are not available to general public and are beyond the scope of this study

Table 5: Mapping of Digital Infrastructure coverage in WDR (source: (ADSL2-Exchanges 2015; RFNSA 2015)

Public Switched Telephone Network (PSTN) coverage of the Towns in the WDR is complete. PSTN provides the underlying infrastructure for broadband ADSL enabled telephone 
exchanges. Almost half of the larger towns (9 out of 20) in the WDR have ADSL enabled exchanges and eight of those towns have access to ADSL2+ broadband services. All ADSL and ADSL2+ broadband infrastructure in WDR is provided by Telstra.

Two fibre optic backbone networks are provided by NextGen Group (www.nextgengroup.com.au) and Nexium Telecommunications (www.nexium.net.au) a subsidiary of Ergon, a State Government electricity utility run through the three major towns in WDR. However these fibre optic backbone networks currently provide wholesale fibre network services which are affordable and accessible only to government entities, ISPs and businesses.

The Telstra 3G mobile network has coverage across the majority of towns Towns in WDR, except for Glenmorgan, Gulugaba, Kaimkillenbun and Macalister. Optus provides $3 \mathrm{G}$ mobile network services in eight towns, Dalby, Chinchilla, Miles, Jandowae, Bell, Wandoan, Dulacca and Warra. Vodafone provides $3 \mathrm{G}$ mobile network services in only three towns, Dalby, Chinchilla and Jandowae. Telstra provides 4G services in 9 towns, Dalby, Chinchilla, Miles, Jandowae, Warra, Drilham, Kogan, Wandoan and Meandarra. Optus provides 4G services in 7 towns, Dalby, Chinchilla, Miles, Jandowae, Bell, Dulacca and Warra. Vodafone provides 4G services in the three largest towns, Dalby, Chinchilla and Miles. When we look at the towns across the WDR by AGSC classification for remoteness we can clearly see that the more remote towns and surrounding localities have poor broadband infrastructure coverage. Some of the remote towns also do not have ADSL enabled telephone exchanges and/or have limited or no 3G mobile network coverage (e.g. Glenmorgan, Gulugaba, Kaimkillenbun and Macalister).

An analysis of the broadband infrastructure in other rural regions of Queensland, Tasmania and New South Wales using the same methodology revealed a similar picture in terms of the availability of broadband infrastructure in rural Australia.

\subsection{Wired and Wireless Broadband Availability Assessment - Selected Rural Regions in Australia}

\subsubsection{Queensland}

\begin{tabular}{|l|c|c|c|c|c|c|c|c|l|}
\hline & Pop & PSTN & ADSL & ADSL2+ & $\begin{array}{c}\text { Fibre optic } \\
\text { backbone }\end{array}$ & $\mathbf{3 G}$ & $\mathbf{4 G}$ & $\begin{array}{c}\text { NBN } \\
\text { Wireless } \\
\mathbf{4 G}\end{array}$ & \multicolumn{1}{|c|}{ ASGC } \\
\hline Warwick & 16,000 & $\mathbf{Y}$ & $\mathbf{Y}$ & $\mathbf{Y}$ & $\mathbf{N}$ & $\begin{array}{c}\mathbf{Y} \\
\text { (All) }\end{array}$ & $\begin{array}{c}\mathbf{Y} \\
\text { (All) }\end{array}$ & $\mathbf{N}$ & $\begin{array}{l}\text { Inner } \\
\text { Regional }\end{array}$ \\
\hline Stanthorpe & 5,500 & $\mathbf{Y}$ & $\mathbf{Y}$ & $\mathbf{Y}$ & $\mathbf{N}$ & $\begin{array}{c}\mathbf{Y} \\
\text { (All) }\end{array}$ & $\begin{array}{c}\mathbf{Y} \\
\text { (All) }\end{array}$ & $\mathbf{Y}$ & $\begin{array}{l}\text { Outer } \\
\text { Regional }\end{array}$ \\
\hline Allora & 1,276 & $\mathbf{Y}$ & $\mathbf{Y}$ & $\mathbf{Y}$ & $\mathbf{N}$ & $\mathbf{Y ( T )}$ & $\mathbf{Y ( T )}$ & $\mathbf{N}$ & $\begin{array}{l}\text { Inner } \\
\text { Regional }\end{array}$ \\
\hline Killarney & 911 & $\mathbf{Y}$ & $\mathbf{Y}$ & $\mathbf{Y}$ & $\mathbf{N}$ & $\begin{array}{c}\mathbf{Y} \\
\text { (All) }\end{array}$ & $\begin{array}{c}\mathbf{Y} \\
(\mathbf{A l l})\end{array}$ & $\mathbf{Y}$ & $\begin{array}{l}\text { Outer } \\
\text { Regional }\end{array}$ \\
\hline The Falls & 197 & $\mathbf{Y}$ & $\begin{array}{c}\mathbf{N} \\
( \pm \mathbf{T})\end{array}$ & $\begin{array}{c}\text { Proposed } \\
\text { (T) }\end{array}$ & $\mathbf{N}$ & $\mathbf{N}$ & $\mathbf{N}$ & $\mathbf{Y}$ & $\begin{array}{l}\text { Outer } \\
\text { Regional }\end{array}$ \\
\hline
\end{tabular}

Table 6: Southern Downs Regional Council (source: (ADSL2-Exchanges 2015; RFNSA 2015))

\begin{tabular}{|l|c|c|c|c|c|c|c|c|c|}
\hline & Pop & PSTN & ADSL & ADSL2+ & $\begin{array}{c}\text { Fibre } \\
\text { optic } \\
\text { backbone }\end{array}$ & $\mathbf{3 G}$ & $\mathbf{4 G}$ & $\begin{array}{c}\text { NBN } \\
\text { Wireless } \\
\text { 4G }\end{array}$ & ASGC \\
\hline Goondiwindi & 6,397 & $\mathbf{Y}$ & $\mathbf{Y}$ & $\mathbf{Y}$ & $\mathbf{N}$ & $\mathbf{Y}$ (All) & Y (All) & Proposed & $\begin{array}{c}\text { Outer } \\
\text { Regional }\end{array}$ \\
\hline Inglewood & 1,069 & $\mathbf{Y}$ & $\mathbf{Y}$ & $\mathbf{Y}$ & $\mathbf{N}$ & $\mathbf{Y}$ (All) & Y (All) & $\mathbf{N}$ & $\begin{array}{c}\text { Outer } \\
\text { Regional }\end{array}$ \\
\hline Texas & $\mathbf{1 , 1 5 9}$ & $\mathbf{Y}$ & $\mathbf{Y}$ & $\mathbf{Y}$ & $\mathbf{N}$ & $\mathbf{Y ( T O )}$ & Y(TO) & Proposed & Remote \\
\hline Yelarbon & 493 & $\mathbf{Y}$ & $\mathbf{Y}$ & $\begin{array}{c}\text { Proposed } \\
\mathbf{( T )}\end{array}$ & $\mathbf{N}$ & $\mathbf{Y ( T O )}$ & $\begin{array}{c}\text { Proposed } \\
\text { (TO) }\end{array}$ & Proposed & $\begin{array}{c}\text { Outer } \\
\text { Regional }\end{array}$ \\
\hline Toobeah & 218 & $\mathbf{Y}$ & $\begin{array}{c}\mathbf{N} \\
\mathbf{(} \mathbf{T})\end{array}$ & $\begin{array}{c}\text { Proposed } \\
\mathbf{( T )}\end{array}$ & $\mathbf{N}$ & Proposed & Proposed & $\mathbf{N}$ & Remote \\
\hline Bungunya & 189 & $\mathbf{Y}$ & $\mathbf{N}$ & $\mathbf{N}$ & $\mathbf{N}$ & $\mathbf{N}$ & $\mathbf{N}$ & $\mathbf{N}$ & Remote \\
\hline
\end{tabular}

Table 7: Goondiwindi Regional Council (source: (ADSL2-Exchanges 2015; RFNSA 2015)) 


\subsubsection{Tasmania}

\begin{tabular}{|l|c|c|c|c|c|c|c|c|c|}
\hline & Pop & PSTN & ADSL & ADSL2+ & $\begin{array}{c}\text { Fibre optic } \\
\text { backbone }\end{array}$ & $\mathbf{3 G}$ & 4G & $\begin{array}{c}\text { NBN } \\
\text { Wireless } \\
\text { 4G }\end{array}$ & ASGC \\
\hline Bagdad & 1,266 & $\mathbf{Y}$ & $\mathbf{Y}$ & $\mathbf{Y}$ & $\mathbf{N}$ & $\begin{array}{c}\text { Y } \\
\text { (All) }\end{array}$ & Y (All) & Proposed & $\begin{array}{c}\text { Outer } \\
\text { Regional }\end{array}$ \\
\hline Mangalore & 521 & $\mathbf{Y}$ & $\mathbf{N}$ & $\mathbf{N}$ & $\mathbf{N}$ & $\mathbf{Y}(\mathbf{T})$ & $\mathbf{Y}$ (T) & Proposed & $\begin{array}{c}\text { Outer } \\
\text { Regional }\end{array}$ \\
\hline Kempton & 353 & $\mathbf{Y}$ & $\mathbf{Y}$ & $\mathbf{Y}$ & $\mathbf{N}$ & $\mathbf{Y ( T )}$ & $\begin{array}{c}\text { Proposed } \\
\text { (T) }\end{array}$ & Proposed & $\begin{array}{c}\text { Outer } \\
\text { Regional }\end{array}$ \\
\hline
\end{tabular}

Table 8: Southern Midlands Council (source: (ADSL2-Exchanges 2015; RFNSA 2015))

\begin{tabular}{|l|c|c|c|c|c|c|c|c|c|}
\hline & Pop & PSTN & ADSL & ADSL2+ & $\begin{array}{c}\text { Fibre optic } \\
\text { backbone }\end{array}$ & $\mathbf{3 G}$ & $\mathbf{4 G}$ & $\begin{array}{c}\text { NBN Wireless } \\
\text { 4G }\end{array}$ & ASGC \\
\hline Queenstown & 1975 & $\mathbf{Y}$ & $\mathbf{Y}$ & $\mathbf{Y}$ & $\mathbf{N}$ & $\begin{array}{c}\text { Y } \\
\text { (TO) }\end{array}$ & $\begin{array}{c}\text { Y } \\
\text { (O) }\end{array}$ & $\mathbf{N}$ & Remote \\
\hline Strahan & 824 & $\mathbf{Y}$ & $\mathbf{Y}$ & $\mathbf{Y}$ & $\mathbf{N}$ & $\mathbf{Y}$ (T) & $\begin{array}{c}\text { Y } \\
\text { (T) }\end{array}$ & Proposed & Remote \\
\hline Rosebery & 922 & $\mathbf{Y}$ & $\mathbf{Y}$ & $\mathbf{Y}$ & $\mathbf{N}$ & $\begin{array}{c}\text { Y } \\
\text { (TO) }\end{array}$ & $\begin{array}{c}\text { Y } \\
\text { (O) }\end{array}$ & $\mathbf{N}$ & Remote \\
\hline $\begin{array}{l}\text { New South } \\
\text { Wales }\end{array}$ & & & & & & & & & \\
\hline
\end{tabular}

Table 9: West Coast Council (source: (ADSL2-Exchanges 2015; RFNSA 2015))

\subsubsection{New South Wales}

\begin{tabular}{|l|c|c|c|c|c|c|c|c|c|}
\hline & Pop & PSTN & ADSL & ADSL2+ & $\begin{array}{c}\text { Fibre optic } \\
\text { backbone }\end{array}$ & $\mathbf{3 G}$ & $\mathbf{4 G}$ & $\begin{array}{c}\text { NBN } \\
\text { Wireless } \\
\mathbf{4 G}\end{array}$ & ASGC \\
\hline Gilgandra & 2,700 & $\mathbf{Y}$ & $\mathbf{Y}$ & $\mathbf{Y}$ & $\mathbf{N}$ & $\begin{array}{c}\text { Y } \\
\text { (All) }\end{array}$ & $\begin{array}{c}\text { Y } \\
\text { (All) }\end{array}$ & $\mathbf{Y}$ & $\begin{array}{c}\text { Outer } \\
\text { Regional }\end{array}$ \\
\hline Tooraweenah & 371 & $\mathbf{Y}$ & $\mathbf{Y}$ & $\mathbf{N}$ & $\mathbf{N}$ & $\begin{array}{c}\text { Y } \\
\text { (TV) }\end{array}$ & $\mathbf{Y ( V )}$ & $\mathbf{N}$ & $\begin{array}{c}\text { Outer } \\
\text { Regional }\end{array}$ \\
\hline Armatree & 284 & $\mathbf{Y}$ & $\begin{array}{c}\mathbf{N} \\
\mathbf{N} \mathbf{T})\end{array}$ & $\begin{array}{c}\text { Proposed } \\
\mathbf{( T )}\end{array}$ & $\mathbf{N}$ & $\mathbf{Y}(\mathbf{T})$ & $\mathbf{N}$ & $\mathbf{N}$ & $\begin{array}{c}\text { Outer } \\
\text { Regional }\end{array}$ \\
\hline
\end{tabular}

Table 10: Gilgandra Shire (source: (ADSL2-Exchanges 2015; RFNSA 2015))

\begin{tabular}{|l|c|c|c|c|c|c|c|c|c|}
\hline & Pop & PSTN & ADSL & ADSL2+ & $\begin{array}{c}\text { Fibre optic } \\
\text { backbone }\end{array}$ & $\mathbf{3 G}$ & $\mathbf{4 G}$ & $\begin{array}{c}\text { NBN } \\
\text { Wireless 4G }\end{array}$ & ASGC \\
\hline Narrabri & 7,392 & $\mathbf{Y}$ & $\mathbf{Y}$ & $\mathbf{Y}$ & $\mathbf{N}$ & $\mathbf{Y}$ (All) & $\begin{array}{c}\text { Y } \\
(\mathbf{A l l})\end{array}$ & $\mathbf{N}$ & $\begin{array}{c}\text { Outer } \\
\text { Regional }\end{array}$ \\
\hline Wee Waa & 2,089 & $\mathbf{Y}$ & $\mathbf{Y}$ & $\mathbf{Y}$ & $\mathbf{N}$ & $\mathbf{Y ( T O )}$ & $\mathbf{Y ( T )}$ & $\mathbf{N}$ & $\begin{array}{c}\text { Outer } \\
\text { Regional }\end{array}$ \\
\hline Baan Baa & 525 & $\mathbf{Y}$ & $\begin{array}{c}\mathbf{N} \\
\mathbf{(} \mathbf{T})\end{array}$ & $\begin{array}{c}\text { Propose } \\
\mathbf{d}(\mathbf{T})\end{array}$ & $\mathbf{N}$ & $\mathbf{Y ( T O )}$ & $\mathbf{Y ( T )}$ & $\mathbf{N}$ & $\begin{array}{c}\text { Outer } \\
\text { Regional }\end{array}$ \\
\hline
\end{tabular}

Table 11: Narrabri Shire (source: (ADSL2-Exchanges 2015; RFNSA 2015))

Legend $\mathrm{Y}=$ Available; $\mathrm{N}$ = Not Available; $\mathrm{T}=$ Telstra $\mathrm{O}=$ Optus; $\mathrm{V}=$ Vodafone $\mathrm{Y}($ All $)$ = Telstra, Optus \& Vodafone; $\mathrm{TO}=$ Telstra \& Optus; $\pm \mathrm{T}=$ Telstra no ports

[Note: these data about broadband availability were captured during the study and may differ that a later time]

\subsection{Results of Testing Mobile Network Services (Telstra, Optus, Vodafone) in WDR}

The selective testing of the mobile network services provided by Telstra, Optus and Vodafone using the Mobile App Open Signal www.opensignal.com on 26-27th February and 10th and 14th March 2014 (See Table 12) showed that the three largest towns in WDR (Dalby, Chinchilla, Miles) all experience good mobile network speed and reliability of service. In contrast, selective testing in smaller towns in the WDR (Condamine, Kogan, Moonie, Drilham) of mobile network services provided by Telstra, Optus and Vodafone showed that speed and reliability of service varied from good, to poor, to non-existent depending on the coverage of mobile phone carrier and the time of day. 


\begin{tabular}{|c|c|c|c|c|c|c|}
\hline Location & Date & Time & $\begin{array}{c}\text { Service } \\
\text { provider }\end{array}$ & Download & Upload & Network type \\
\hline \multirow{5}{*}{ Dalby } & \multirow{4}{*}{$26 / 02 / 14$} & \multirow{3}{*}{ 7:15 am } & Telstra & 13.24 Mbps & $3.48 \mathrm{Mbps}$ & $4 \mathrm{G}$ \\
\hline & & & Vodafone & $7.15 \mathrm{Mbps}$ & $2.67 \mathrm{Mbps}$ & $3 \mathrm{G}$ \\
\hline & & & Optus & $1.82 \mathrm{Mbps}$ & $484 \mathrm{Kbps}$ & $3 \mathrm{G}$ \\
\hline & & $4: 13 \mathrm{pm}$ & Telstra & 16.01 Mbps & 4.07 Mbps & $4 \mathrm{G}$ \\
\hline & $27 / 02 / 14$ & $1: 47 \mathrm{pm}$ & Telstra & $17.33 \mathrm{Mbps}$ & 3.30 Mbps & $4 \mathrm{G}$ \\
\hline & \multirow{4}{*}{$26 / 02 / 14$} & \multirow{4}{*}{ 11:10 am } & & & & \\
\hline \multirow{3}{*}{ Chinchilla } & & & Telstra & 28.1 Mbps & 2.9 Mbps & $4 \mathrm{G}$ \\
\hline & & & Vodafone & $2.4 \mathrm{Mbps}$ & $2 \mathrm{Mbps}$ & $3 \mathrm{G}$ \\
\hline & & & Optus & $677 \mathrm{Kbps}$ & $409 \mathrm{Kbps}$ & $3 \mathrm{G}$ \\
\hline & & & & & & \\
\hline \multirow{4}{*}{ Miles } & $14 / 01 / 14$ & 01:52pm & Optus & 1.54 Mbps & $410 \mathrm{Kbps}$ & $3 \mathrm{G}$ \\
\hline & \multirow{3}{*}{$14 / 03 / 14$} & \multirow{3}{*}{ o8:22am } & Telstra & 19.52 Mbps & $17.7 \mathrm{Mbps}$ & LTE-4G \\
\hline & & & Vodafone & $9.14 \mathrm{Mbps}$ & $2.22 \mathrm{Mbps}$ & HSPA \\
\hline & & & Optus & 1.52 Mbps & $420 \mathrm{Kbps}$ & $3 \mathrm{G}$ \\
\hline Condamine & $26 / 02 / 14$ & $12: 12 \mathrm{pm}$ & Telstra & $9.46 \mathrm{Mbps}$ & $769 \mathrm{kbps}$ & HSPA \\
\hline \multirow[b]{2}{*}{ Kogan } & $26 / 02 / 14$ & $3: 45 \mathrm{pm}$ & Telstra & $5.18 \mathrm{Mbps}$ & $627 \mathrm{Kbps}$ & HSPA \\
\hline & $10 / 03 / 14$ & $3: 51 \mathrm{pm}$ & Telstra & $9.89 \mathrm{Mbps}$ & $1.419 \mathrm{Mbps}$ & HSPA \\
\hline & & & & & & \\
\hline \multirow{2}{*}{ Moonie } & \multirow{2}{*}{$10 / 03 / 14$} & \multirow{2}{*}{$8: 39 \mathrm{am}$} & Telstra & 3.5 Mbps & $99 \mathrm{Kbps}$ & $\begin{array}{l}\text { 3G/ HSPA (with signal } \\
\text { booster) }\end{array}$ \\
\hline & & & Telstra & N/A & $105 \mathrm{Kbps}$ & $\begin{array}{c}\text { HSPA (without signal } \\
\text { booster) }\end{array}$ \\
\hline \multirow{2}{*}{ Drillham } & \multirow{2}{*}{$14 / 03 / 14$} & \multirow{2}{*}{ 10:29 am } & Telstra & $2.53 \mathrm{Mbps}$ & $476 \mathrm{Kbps}$ & $3 \mathrm{G}$ \\
\hline & & & Optus & $470 \mathrm{Kbps}$ & $80 \mathrm{Kbps}$ & $3 \mathrm{G}$ \\
\hline
\end{tabular}

[Note: these download and upload speeds were captured during the study which may be differ at a later point in time]

Table 12: Selective Testing using OpenSignal Mobile App Three Carriers - Mobile Networks in the WDR

In summary, from the analysis of the data sources from the RFNSA website and the results of the mobile network services testing with the Open Signal Mobile App we were able to determine availability and reliability of mobile broadband services in the WDR. The proprietary radio networks which have extensive coverage in the WDR are not listed in Table 5 because these networks are dependent on the capability of specific organisations and individuals to set up and maintain the infrastructure to these radio networks.

\subsection{Discussion of household use and satisfaction with broadband services in WDR}

In this section we present and discuss the results of the household survey in the WDR in terms of the demographics of the respondent households and their use and satisfaction with the available broadband services. Note, all of the respondent households in this survey were using the Internet.

\subsubsection{Household use of broadband services}

To understand household use of broadband services in the WDR, survey respondents were asked the following questions.

1. Does your household have access to the internet? (Filter question)

2. How long has your household been using the internet?

3. What kind of internet connection is used in your household?

4. How often each week does your household use internet services?

5 . How many members of your household use the internet? 
6. Where do members of your household access the internet?

7. Which of these devices are used by households to access the internet?

8. What activities does your household use the Internet for?

Now we discuss the survey results for each of these questions in turn below.

Three quarters of households have been using the internet for six or more years. Interestingly, almost $40 \%$ of households started using the internet more than 16 years ago when the primary means of accessing the internet was via narrowband and a dialup modem. Moreover, $60 \%$ of households started using the internet since ADSL broadband internet services became readily available across Australia from 2005 when Telstra started to roll out ADSL enabled telephone exchanges en masse across the country (Fletcher 2009; Islam, Selvadurai \& Town 2008). More recently, the roll out of mobile broadband has also contributed to an increase in the adoption and use of the internet by households.

The most widely used internet connection technologies in the WDR are $3 \mathrm{G} / 4 \mathrm{G}$ mobile broadband (60\%), ADSL/ADSL2+ broadband (48\%) and satellite broadband (10\%). The majority of households (76\%) are accessing the internet on a daily basis

Ninety-eight percent of households are accessing the internet from their home, while almost $56 \%$ of households are accessing the internet from work; $27 \%$ from school, TAFE or university; $19 \%$ from public places; and 10\% from a library. These findings are consistent with ACMA (2015) survey data which shows that home remains the main location where household members go online. However, it may be that this will change over time as mobile broadband becomes increasingly available and persuasive.

At $80 \%$, laptops and notebooks are the most common devices used by households to access the internet. At $64 \%$, Smart phones are the second most common device used by households to access the internet. At $57 \%$, desktop computers are the third most common device used by households to access the Internet; while at $55 \%$, tablets are the fourth most common device used by households to access the Internet. To a lesser extent-at $15 \%$ and $13 \%$ respectivelygaming consoles and internet TV are the fifth and sixth most common ways to access the internet. Here, internet TV is defined as an internet enabled TV which could connect through a home network to access the internet. These results are also somewhat aligned with the national level aggregated data (ABS 2016) where most households accessed the internet through a desktop or laptop computer (94\%), followed by mobile or smart phones (86\%) and tablets (62\%).

The top ten internet based digital services used by respondent households in the WDR were as follows. Email is most widely used (97\%); and, not surprisingly, online banking and social media (Facebook) also figure prominently. E-Government services come in at number 10 (47\%) with almost half of the respondent households using government internet based digital services. Overall, the survey results from WDR households demonstrate that the use of internet services is similar to the results of a recent national level study of households conducted by ABS (2016) where the most popular activities are banking, social networking, services, online shopping and entertainment.

\subsubsection{User satisfaction with broadband services}

Household satisfaction with their broadband service(s) was measured in terms of affordability and overall satisfaction with their current broadband service(s). Figure 4 shows the respondent household beliefs regarding affordability of their broadband service(s). 


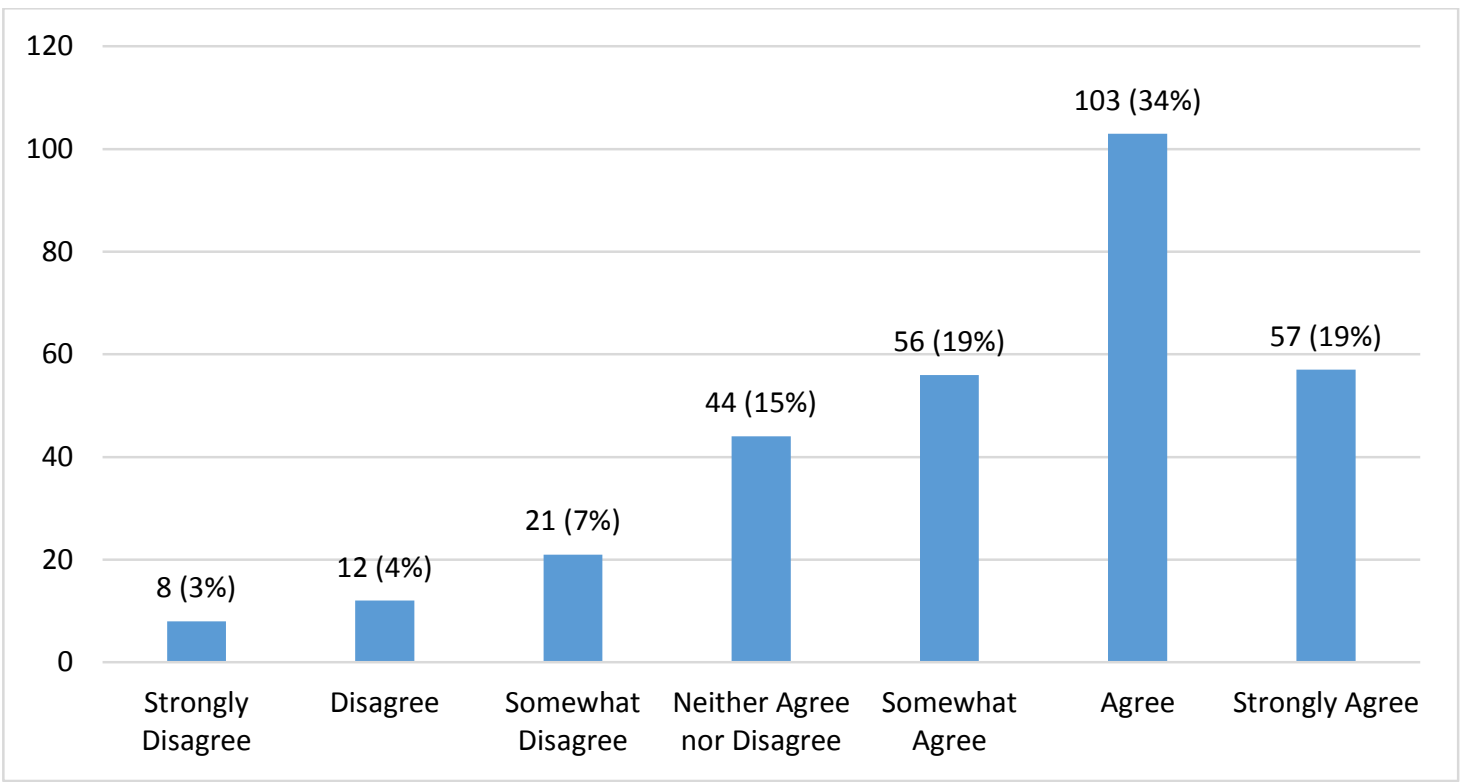

Figure 4: Respondent household beliefs regarding affordability of broadband internet in the WDR $N=301$ (Source: this research)

For the survey question: "My annual household income is enough to afford subscribing to broadband internet" Seventy two percent of respondent households agree that their broadband internet service is affordable; while $14 \%$ of households disagree that their broadband internet service is affordable; and $15 \%$ of households are undecided. Hence, a small but significant proportion of the sample population in this study felt that broadband services were expensive and this is most likely to be outer regional and remote locations in the WDR where only mobile broadband services are available. It should be noted that the WDR has lower socio-economic status than major urban areas in Queensland such as Toowoomba and Brisbane (Queensland Government 2014). Table 13 breaks down household perception of broadband affordability by the type of broadband service. Here we see some interesting trends emerge.

\begin{tabular}{|c|c|c|c|c|c|c|c|c|c|}
\hline & 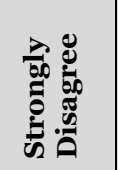 & 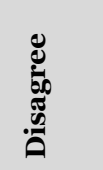 & 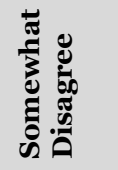 & 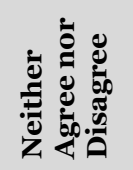 & 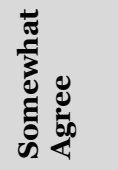 & 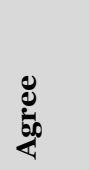 & 离 & 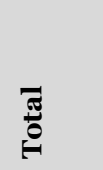 & 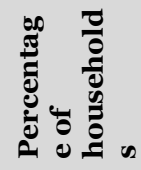 \\
\hline 3G/4G (mobile) & $4 \%$ & $6 \%$ & $8 \%$ & $11 \%$ & $19 \%$ & $35 \%$ & $18 \%$ & 181 & $60 \%$ \\
\hline ADSL/ADSL2+ & $1 \%$ & $1 \%$ & $4 \%$ & $11 \%$ & $18 \%$ & $40 \%$ & $25 \%$ & 145 & $48 \%$ \\
\hline Satellite & & & $3 \%$ & $24 \%$ & $10 \%$ & $38 \%$ & $24 \%$ & 29 & $10 \%$ \\
\hline Dial-up & & & $40 \%$ & $0 \%$ & & & $20 \%$ & 5 & $\%$ \\
\hline
\end{tabular}

Table 13: Affordability for each type of Broadband service (Source: this research)

Broadband services are perceived to be affordable by the majority of the respondent households (3G/4G 72\%; ADSL/ADSL2+ 83\%; Satellite 72\%); whereas only a small number of households indicated that affordability of broadband services was an issue $(3 \mathrm{G} / 4 \mathrm{G} 18 \%$; ADSL/ADS2+ 6\%; Satellite 3\%). Interestingly, there were a number of households that were undecided about the affordability of broadband services (3G/4G 11\%; ADSL/ADS2+ 11\%; Satellite 24\%). The number of households still using narrowband dial-up internet service is very low so it is difficult to comment on this other than to note that the use of this service has become almost non-existent and many ISPs no longer offer this type of service. Further Table 14 breaks down household perception of broadband affordability by the type of broadband service across remoteness classifications for WDR. 


\begin{tabular}{|c|c|c|c|c|c|c|c|c|c|}
\hline 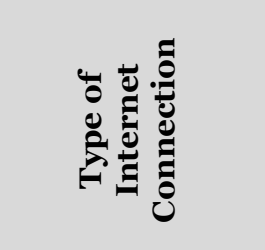 & 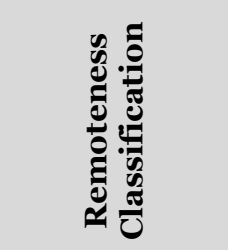 & 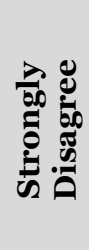 & 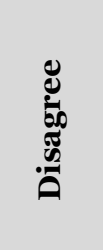 & 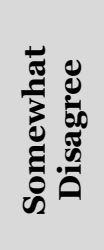 & 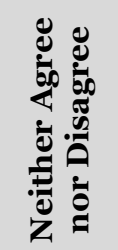 & 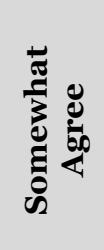 & סू & 离 & 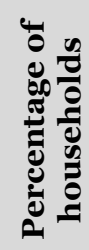 \\
\hline \multirow[t]{3}{*}{ 3G/4G (mobile) } & Inner Regional & & $5.7 \%$ & $5.7 \%$ & $12.9 \%$ & $14.3 \%$ & $35.7 \%$ & $25.7 \%$ & $60 \%$ \\
\hline & Outer Regional & $6.7 \%$ & $4.4 \%$ & $7.8 \%$ & $8.9 \%$ & $24.4 \%$ & $32.2 \%$ & $15.6 \%$ & \\
\hline & Remote & $4.8 \%$ & $9.5 \%$ & $14.3 \%$ & $14.3 \%$ & $14.3 \%$ & $42.9 \%$ & & \\
\hline \multirow[t]{3}{*}{ ADSL/ADSL2+ } & Inner Regional & & $1.1 \%$ & $4.5 \%$ & $11.4 \%$ & $21.6 \%$ & $38.6 \%$ & $22.7 \%$ & $48 \%$ \\
\hline & Outer Regional & $2.0 \%$ & & $2.0 \%$ & $10.2 \%$ & $14.3 \%$ & $40.8 \%$ & $30.6 \%$ & \\
\hline & Remote & & $12.5 \%$ & $12.5 \%$ & $12.5 \%$ & & $50.0 \%$ & $12.5 \%$ & \\
\hline \multirow[t]{3}{*}{ Satellite } & Inner Regional & & & & $100.0 \%$ & & & & $10 \%$ \\
\hline & Outer Regional & & & & $12.5 \%$ & $18.8 \%$ & $43.8 \%$ & $25.0 \%$ & \\
\hline & Remote & & & $9.1 \%$ & $27.3 \%$ & & $36.4 \%$ & $27.3 \%$ & \\
\hline \multirow[t]{3}{*}{ Dial-up } & Inner Regional & & & & $50.0 \%$ & & & $50.0 \%$ & $2 \%$ \\
\hline & Outer Regional & & & $66.7 \%$ & $33.3 \%$ & & & & \\
\hline & Remote & & & & & & & & \\
\hline
\end{tabular}

Table 14: Affordability for each type of Broadband service across remoteness classifications in WDR

Table 14 shows that remote households are more concerned about the affordability of Broadband services compared to outer and inner regional households.

Households were asked whether they were satisfied with their current broadband service and plan. Figure 5 shows the level of satisfaction with the current broadband service and plan used by the respondent households

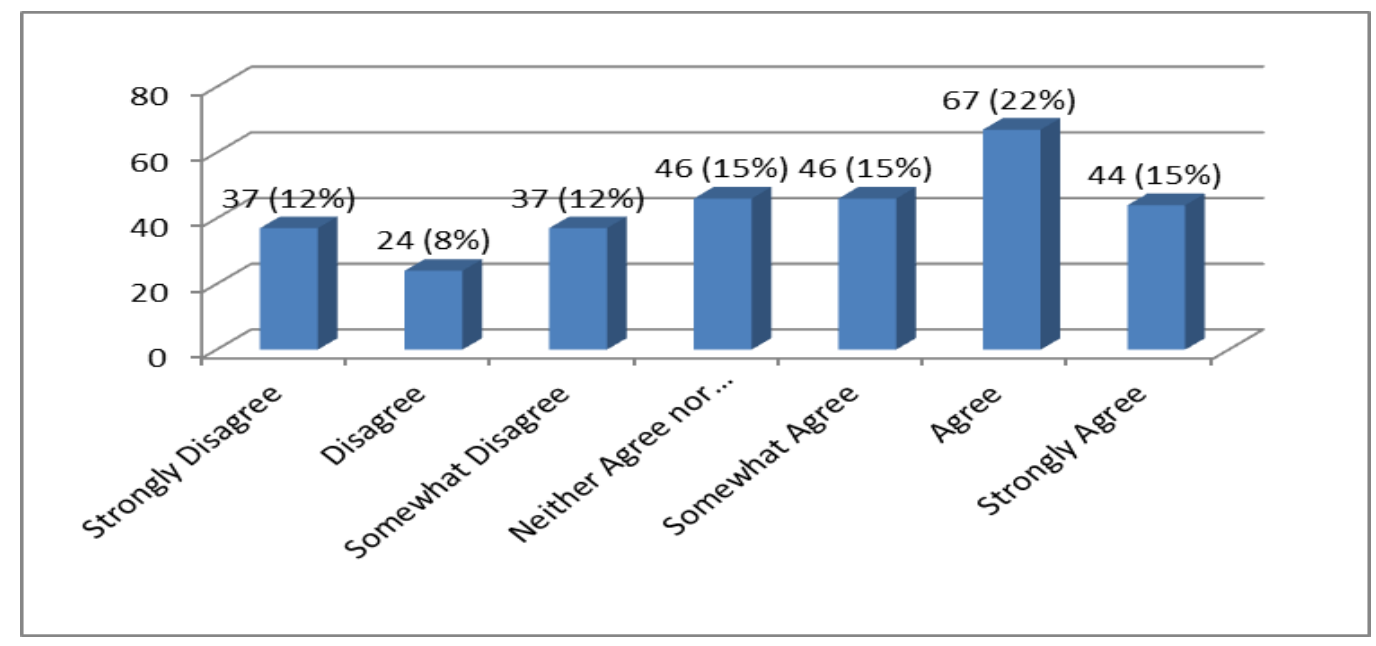

Figure 5: Household satisfaction with broadband services $N=301$ (Source: this research)

Interestingly, 32\% of respondent households are dissatisfied with their current broadband service and plan, while 52\% of the respondent households are satisfied with their broadband services and $15 \%$ of respondent households are non-committal about their satisfaction with their broadband services.

Table 15 breaks down the level of household satisfaction with broadband services by the type of broadband service. Here we see some interesting trends emerge. 


\begin{tabular}{|c|c|c|c|c|c|c|c|c|c|}
\hline & 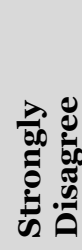 & 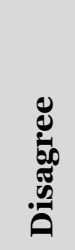 & 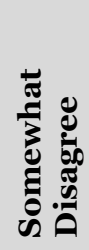 & 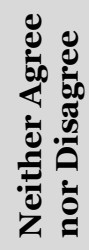 & 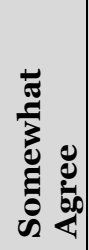 & 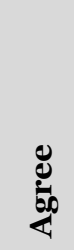 & 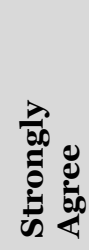 & $\overbrace{0}^{\bar{\sigma}}$ & 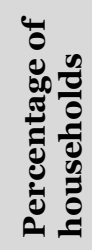 \\
\hline $3 \mathrm{G} / 4 \mathrm{G}$ & $15 \%$ & $8 \%$ & $13 \%$ & $17 \%$ & $12 \%$ & $22 \%$ & $12 \%$ & 181 & $60 \%$ \\
\hline ADSL/ADSL2+ & $4 \%$ & $6 \%$ & $10 \%$ & $17 \%$ & $19 \%$ & $27 \%$ & $17 \%$ & 145 & $48 \%$ \\
\hline Satellite & $21 \%$ & $10 \%$ & $17 \%$ & $10 \%$ & $17 \%$ & $17 \%$ & $7 \%$ & 29 & $10 \%$ \\
\hline Dial-up & & $20 \%$ & $20 \%$ & & & & $60 \%$ & 5 & $2 \%$ \\
\hline
\end{tabular}

Table 15: Level of satisfaction with type of broadband service (Source: this research)

The level of satisfaction with ADSL broadband services is much higher (63\%) compared to $3 \mathrm{G} / 4 \mathrm{G}$ mobile broadband services (46\%) and satellite broadband services (41\%). Similarly, the level of dissatisfaction with ADSL broadband services is much less (20\%) compared to $3 \mathrm{G} / 4 \mathrm{G}$ mobile broadband services (36\%) and satellite broadband services (48\%). This is not surprising given that ADSL/ADSL2+ broadband services are faster and cheaper when compared to mobile broadband services. This supports our previous findings in relation to the supply of broadband infrastructure that $3 \mathrm{G} / 4 \mathrm{G}$ mobile broadband services and satellite broadband services are much more variable in terms of coverage, speed and reliability of service than fixed line ADSL broadband services, hence, the lower levels of satisfaction. Dialup narrowband services have such a low usage these days that we consider its impact in the WDR to be negligible.

Further Table 16 breaks down the level of household satisfaction with broadband services by the type of broadband service across remoteness in WDR.

\begin{tabular}{|c|c|c|c|c|c|c|c|c|c|}
\hline 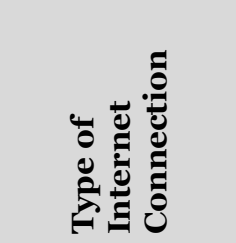 & 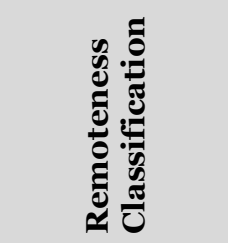 & 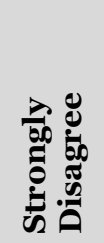 & 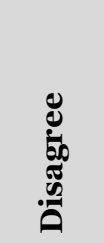 & 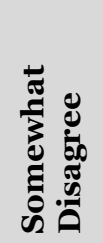 & 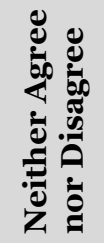 & 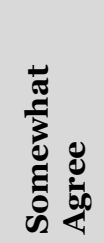 & סू & 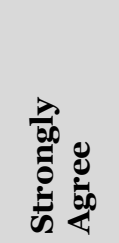 & 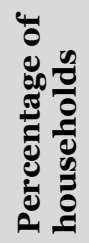 \\
\hline \multirow{3}{*}{$3 \mathrm{G} / 4 \mathrm{G}$ (mobile) } & Inner Regional & $12.9 \%$ & $4.3 \%$ & $7.1 \%$ & $20.0 \%$ & $14.3 \%$ & $28.6 \%$ & $12.9 \%$ & $60 \%$ \\
\hline & Outer Regional & $13.3 \%$ & $10.0 \%$ & $18.9 \%$ & $15.6 \%$ & $11.1 \%$ & $16.7 \%$ & $14.4 \%$ & \\
\hline & Remote & $33.3 \%$ & $9.5 \%$ & $9.5 \%$ & $14.3 \%$ & $9.5 \%$ & $23.8 \%$ & & \\
\hline \multirow{3}{*}{ ADSL/ADSL2+ } & Inner Regional & $3.4 \%$ & $6.8 \%$ & $5.7 \%$ & $18.2 \%$ & $18.2 \%$ & $29.5 \%$ & $18.2 \%$ & $48 \%$ \\
\hline & Outer Regional & $4.1 \%$ & $2.0 \%$ & $20.4 \%$ & $16.3 \%$ & $20.4 \%$ & $20.4 \%$ & $16.3 \%$ & \\
\hline & Remote & $12.5 \%$ & $12.5 \%$ & & & $25.0 \%$ & $37.5 \%$ & $12.5 \%$ & \\
\hline \multirow{3}{*}{ Satellite } & Inner Regional & & & & & & $100.0 \%$ & & $10 \%$ \\
\hline & Outer Regional & $25.0 \%$ & $6.3 \%$ & $18.8 \%$ & $12.5 \%$ & $25.0 \%$ & $6.3 \%$ & $6.3 \%$ & \\
\hline & Remote & $18.2 \%$ & $18.2 \%$ & $18.2 \%$ & $9.1 \%$ & $9.1 \%$ & $18.2 \%$ & $9.1 \%$ & \\
\hline \multirow{3}{*}{ Dial-up } & Inner Regional & & & & & & & $100.0 \%$ & $2 \%$ \\
\hline & Outer Regional & & $33.3 \%$ & $33.3 \%$ & & & & $33.3 \%$ & \\
\hline & Remote & & & & & & & & \\
\hline
\end{tabular}

Table 16: Level of satisfaction with type of broadband service across remoteness in WDR (Source: this research)

Table 16 shows that remote households and to a lesser degree outer regional households have higher levels of dissatisfaction with broadband services than inner regional households. We acknowledge the satisfaction of households with their broadband service is based on the perceptions of the major decision maker-the household survey respondent in terms of the type of broadband service that is available to them-and that is a limitation of this study. However, we believe that most rural households, even if they do not have access to a fast and reliable broadband service, are well aware-through their network of relatives, friends and work colleagues-that much better wired and wireless broadband services are available in 
larger population centres in the WDR and in major urban centres throughout Queensland and Australia. This may be the reason for users' dissatisfaction with their current Internet services. The cost of broadband services does not appear to be a major cause of household dissatisfaction with broadband services in WDR. However in the remote and outer regions of WDR in many instances only mobile broadband is available which is much more expensive in comparison to wired broadband services such as ADSL1/ADSL2 (See comparison of mobile broadband services versus ADSL1/ADSL2+ on price and data quotas in Appendix 1).

\section{Conclusion and Implications}

This research has made a number of significant theoretical and practical contributions to existing knowledge. Historically, information systems research has missed opportunities to make a significant theoretical and practical contribution by adopting a limited perspective, improving performance of the organisation as a unit of analysis - while ignoring the important challenges facing society (Clarke 2015). In our adapted broadband ecosystem model we examined the important relationship between supply of broadband infrastructure and household use and satisfaction with broadband services which is likely to influence the perceived benefits of broadband services in rural Australia. This research also addressed another gap in information systems research-the lack of empirical research on broadband infrastructure. Tilson, Lyytinen and Sørensen (2010) referred to digital infrastructure research as the orphan of information systems research and an under researched and important area of research. This research has made a number of significant practical contributions which can inform government policy by identifying that availability, reliability and affordability shortcomings of broadband infrastructure in outer regional and remote regions is impacting household use and satisfaction with broadband services in rural Australia.

This paper presented some key findings regarding the relationship between the supply of broadband access technologies and household use and satisfaction with broadband services in WDR. Mobile broadband is highly variable in terms of speed and reliability across the region and is much more restrictive in terms of data quotas than ADSL-which also makes it a much more expensive broadband service. ADSL broadband is only available in 9 of the 20 towns in the WDR. Our findings suggest that the variability and cost of wireless (mobile, satellite) broadband in WDR would appear to be contributing to household dissatisfaction with broadband services particular in remote and outer regional locations.

Our findings identified the limitations in the supply of broadband infrastructure in the remote and outer regions, and that household dissatisfaction with current mobile broadband services is clearly evident in these locations. To lesser extent given the reliance of remote and outer regions on mobile broadband, affordability of broadband is also an issue for households given the lower socio-economic status of much of rural Australia including WDR. Hence, there would also appear to be a digital divide particularly between the remote and outer regions of WDR and inner regions and urban areas of Australian. Overall our analysis of broadband infrastructure indicates that a lack of reliable and affordable broadband services due to rural Australia's reliance on wireless broadband could be a limiting factor for rural regions such as WDR being able to successfully transition to the digital economy.

We believe that this current situation also exists in much of rural Australia which suffers from inadequate provision of reliable broadband infrastructure as evidenced by the analysis of the supply of broadband infrastructure presented in this paper. This situation is also detrimental to the short term and long term growth of economic, human and social capital in rural regions such as the WDR. The key findings of this paper, we believe, have significant implications for national, state and local government in terms of broadband policy. We argue that government and policy makers should consider including high speed broadband access as part of the Universal Service Obligation (USO) to ensure that rural and regional Australia is not disadvantaged in a digital future. Clearly in rural Australia, wireless broadband networks (mobile broadband, broadband satellite) are the dominant broadband access technology on which most rural communities are highly reliant. This study identified poor network coverage 
and highly variable quality of service for these wireless broadband networks in rural Australia, suggesting that a digital divide still exists between much of rural Australia and urban Australia. Future government policy needs to address the lack of government investment in the backbone broadband infrastructure in rural Australia which is needed to underpin high speed wireless broadband in rural Australia.

Finally, future thought and consideration needs to be given to correcting the current failure of telecommunication markets to address the shortcomings of wireless broadband networks in rural Australia. We believe this market failure could be addressed in part through subsidies, including access to broadband as part of the Universal Service Obligation which currently only considers access to a fixed telephone service.

\section{Acknowledgements}

We would like to acknowledge the assistance and support that we received from Craig Tunley, the Senior Economic Development Officer at Western Downs Regional Council and the Western Downs Regional Council to conduct this research. We would also like to acknowledge the support and guidance we received from Professor Julie Cotter, the Director of the Australian Centre for Sustainable Business and Development to conduct this research. Finally, we wish to acknowledge the academic staff at University of Southern Queensland who assisted us with the pre-test of the survey instrument developed for this research.

\section{References}

ABS 2013a, 8153.o - Internet Activity, Australia, June 2013, 08 Oct 2013, ABS, Canberra, 1 December 2014, 8135, <http://www.abs.gov.au/AUSSTATS/abs@.nsf/Lookup/8153.oMain+Features1June\% 202013?OpenDocument>.

ABS 2013b, '8153.0 - Internet Activity, Australia', viewed 20th September 2013, <http://www.abs.gov.au/AUSSTATS/abs@.nsf/DetailsPage/8153.oJune\%202013?Ope nDocument $>$.

ABS 2014, Australian Statistical Geography Standard (ASGS), Australian Bureau of $\begin{array}{llll}\text { Statistics, } & \text { viewed } & 15 & \text { December }\end{array}$ <http://www.abs.gov.au/websitedbs/D3310114.nsf/home/Australian+Statistical+Geog raphy+Standard+\%28ASGS\%29>.

ABS 2015, Type of access connection, Australian Bureau of Statistics, viewed 20 October 2015, <http://www.abs.gov.au/AUSSTATS/abs@.nsf/Lookup/8153.oMain+Features1June\% 202015?OpenDocument>.

ABS 2016, Household Use of Information Technology, Australia, 2014-15, Australian Bureau of Statistics, CANBERRA, <http://www.abs.gov.au/ausstats/abs@.nsf/mf/8146.o>.

ACMA 2015, Communications report 2013-14 series Report 1-Australians' digital lives Australian Communications and Media Authority, viewed 20 May 2015, <http://www.acma.gov.au/ /media/Research\%20and\%20Analysis/Research/pdf/Aus tralians\%20digital\%2olivesFinal\%2opdf.pdf $>$.

ADSL2-Exchanges 2015, ADSL2 Exchanges, viewed 25 October 2015, <http://www.adsl2exchanges.com.au/>.

Alam, K \& Imran, S 2015, "The digital divide and social inclusion among refugee migrants: A case in regional Australia', Information Technology \& People, vol. 28, no. 2, pp. 344-65.

Arai, Y, Naganuma, S \& Satake, Y 2012, 'Local government broadband policies for areas with limited Internet access. An analysis based on survey data from Japan', Networks and Communication Studies, vol. 26, no. 3-4, pp. 251-74.

AWD 2015, Our Region, Advance Western Downs, viewed 15 December 2015, <http://www.advancewesterndowns.com.au/our-region/>. 
Bandias, S \& Ram Vemuri, S 2005, 'Telecommunications infrastructure facilitating sustainable development of rural and remote communities in Northern Australia', Telecommunications Policy, vol. 29, no. 2, pp. 237-49.

Brown, SA \& Venkatesh, V 2005, 'Model of adoption of technology in households: A baseline model test and extension incorporating household life cycle', MIS quarterly, vol. 29, no. 3, pp. 399-426.

Budde, P 2014, 'Global - BuddeComm's International Broadband and Trans-sector Activities', viewed 20th October 2014, <http://www.budde.com.au/>.

Chaleyer-Kynaston, M 2012, Wi-Fi vs. Wireless Broadband, ABC Open news, viewed 5 March 2016, <https://open.abc.net.au/explore/10378>.

Clarke, R 2015, 'Not Only Horses Wear Blinkers: The Missing Perspectives in IS Research', Keynote Paper in proceedings of the Australasian Conference on Information Systems Adelaide, Australia, 2 - 4 December 2015.

Cohen, WM \& Levintbal, DA 1990, 'Absorptive Capacity: A New Perspective on Learning and Innovation', Administrate Science Quarterly, vol. 35, no. 1, pp. 128-52.

Davis, T n.d., Queensland Australia map - Queensland Map Australia, viewed 10 December 2015, <http://australiaresorts.us/cat13/queensland-australia-map.html>

Dobson, P, Jackson, P \& Gengatharen, D 2013, 'Explaining Broadband Adoption in Rural Australia: Modes of Reflexivity and the Morphogenetic Approach', MIS quarterly, vol. 37, no. 3, pp. 965-91.

Dwivedi, YK, Choudrie, J \& Brinkman, W-P 2006, 'Development of a survey instrument to examine consumer adoption of broadband', Industrial Management \& Data Systems, vol. 106, no. 5, pp. 700-18.

Dwivedi, YK, Alsudairi, MA \& Irani, Z 2010, 'Explaining factors influencing the consumer adoption of broadband', International Journal of Business Information Systems, vol. 5, no. 4 , pp. 393-417.

Federal Communications Commission 2010, Connecting America: The national broadband plan, Federal Communications Commission, Washington DC, <https://www.fcc.gov/general/national-broadband-plan>.

Fletcher, P 2009, Wired Brown Land: Telstra's Battle for Broadband, UNSW Press.

Given, J 2008, 'Australia's broadband: How big is the problem?', Media International Australia, vol. 127, no. 1, pp. 6-10.

Gruber, H, Hätönen, J \& Koutroumpis, P 2014, 'Broadband access in the EU: An assessment of future economic benefits', Telecommunications Policy, vol. 38, no. 11, pp. 1046-58.

Grubesic, TH 2012, 'The US National Broadband Map: data limitations and implications', Telecommunications Policy, vol. 36, no. 2, pp. 113-26.

Hill, SR, Burgan, B \& Troshani, I 2011, 'Understanding broadband adoption in rural Australia', Industrial Management \& Data Systems, vol. 111, no. 7, pp. 1087-104.

Hill, SR, Troshani, I \& Burgan, B 2014, 'Broadband adoption in regional and urban households', Journal of Computer Information Systems, vol. 54, no. 3, pp. 57-66.

Hollifield, C \& Donnermeyer, JF 2003, 'Creating demand: influencing information technology diffusion in rural communities', Government Information Quarterly, vol. 20, no. 2, pp. 135-50.

Hudson, HE 2013, 'Beyond Infrastructure: Broadband for Development in Remote and Indigenous Regions', Journal of Rural and Community Development, vol. 8, no. 2, pp. 44-61. 
Islam, AR, Selvadurai, N \& Town, G 2008, 'Wireless broadband technologies for regional and rural Australia: A last-mile perspective', Telecommunications Journal of Australia, vol. 58, no. 2-3, pp. 28.1-.18.

Kawade, S \& Nekovee, M 2012, 'Is wireless broadband provision to rural communities in TV whitespaces viable? a UK case study and analysis', in proceedings of the IEEE International Symposium on Dynamic Spectrum Access Networks (DYSPAN), IEEE, Bellevue, WA, USA, pp. 461-6, 16-19 Oct. 2012

Kelly, T \& Rossotto, CM 2012, Broadband strategies handbook, World Bank Publications, Washington, D.C.

Kerpez, K, Cioffi, J, Ginis, G, Goldburg, M, Galli, S \& Silverman, P 2014, 'Software-defined access networks', Communications Magazine, IEEE, vol. 52, no. 9, pp. 152-9.

Lehr, W \& Chapin, J 2009, 'Rethinking Wireless Broadband Platforms', in proceedings of the Wireless Technologies: Enabling Innovation and Growth Georgetown Center for Business and Public Policy, Washington DC, April 2009.

Middleton, C \& Chang, S 2008, 'The adoption of broadband internet in Australia and Canada', in YK Dwivedi, et al. (eds), Handbook of research on global diffusion of broadband data transmission, IGI Global, London, vol. 1, pp. 820-42.

Middleton, C \& Park, S 2014, 'Waiting for the national broadband network: Challenges of connectivity in regional Australia', in proceedings of the 2oth ITS Biennial Conference Econstor, Rio de Janeiro, Brazil, 30 Nov. - 03 Dec. 2014.

National Broadband Network 2014, Broadband, NBN Co, viewed 01 February 2014, $<$ http://www.nbnco.com.au/glossary.html>.

OECD 2014, Broadband access, Organisation for Economic Co-operation and Development, viewed 01 February 2014, <https://data.oecd.org/broadband/wireless-mobilebroadband-subscriptions.htm>.

OpenSignal 2014, Open signal, viewed 10 December 2013, <http://opensignal.com/>.

Park, S, Freeman, J, Middleton, C, Allen, M, Eckermann, R \& Everson, R 2015, 'The MultiLayers of Digital Exclusion in Rural Australia', in proceedings of the 48th Hawaii International Conference on System Sciences (HICSS) IEEE, Hawaii pp. 3631-40, January $5^{\text {th }}-8$ th, 2015.

Prieger, JE 2013, "The broadband digital divide and the economic benefits of mobile broadband for rural areas', Telecommunications Policy, vol. 37, no. 6, pp. 483-502.

Queensland Government 2014, Queensland Regional Profiles, Queensland Government, viewed 20 January 2016, <http://statistics.qgso.qld.gov.au/qld-regional-profiles>.

Rajabiun, R \& Middleton, CA 2013, 'Multilevel governance and broadband infrastructure development: Evidence from Canada', Telecommunications Policy, vol. 37, no. 9, pp. 702-14.

RFNSA 2016, Radio Frequency National Site Archive, viewed 25 March 2016, <http://www.rfnsa.com.au/nsa/index.cgi>.

RTIRC 2015, Regional Telecommunications Review 2015, Australian Government, viewed 15 December 2015, <http://www.rtirc.gov.au/wpcontent/uploads/sites/2/2015/10/RTIRC-Independent-Committee-Review-2015FINAL-Low-res-version-for-website.pdf $>$.

Seymour, LF \& Naidoo, M 2013, 'The Usage and Impact of Broadband: A South African Household analysis', Electronic Journal of Information Systems Evaluation, vol. 16, no. 2, pp. 134-47. 
Stern, SE, Gregor, S, Martin, MA, Goode, S \& Rolfe, J 2004, 'A classification tree analysis of broadband adoption in Australian households', in proceedings of the 6th international conference on Electronic commerce ACM, Delft, The Netherlands, pp. 451-6, October 25-27, 2004.

Straub, D, Boudreau, M-C \& Gefen, D 2004, 'Validation guidelines for IS positivist research', Communications of the Association for Information Systems, vol. 13, no. 24, pp. 380427.

Tilson, D, Lyytinen, K \& Sørensen, C 2010, 'Research commentary-digital infrastructures: the missing IS research agenda', Information Systems Research, vol. 21, no. 4, pp. 748-59.

Touré, DHIIS-G 2014, Commiting to connecting the World: Introduction, viewed 2nd January 2014, <http://www.itu.int/en/action/broadband/Pages/intro.aspx>.

Wallsten, S \& Mallahan, C 2010, Residential broadband competition in the United States, Available at SSRN: http://dx.doi.org/10.2139/ssrn.1684236

WDR 2015, The Western Downs at a Glance, viewed November 15 2015, $<$ http://www.westerndownsregion.com.au/html/profile.asp >.

WDRC 2015, Western Downs economic annual 2015 January, Advance Western Downs viewed 27 May 2015, <http://www.advancewesterndowns.com.au/?s=Western+Downs+economic+annual+ 2015+January $>$.

Whitacre, B, Gallardo, R \& Strover, S 2014, 'Broadband' s contribution to economic growth in rural areas: Moving towards a causal relationship', Telecommunications Policy, vol. 38 , no. 11 , pp. 1011-23.

Whitacre, B, Strover, S \& Gallardo, R 2015, 'How much does broadband infrastructure matter? Decomposing the metro-non-metro adoption gap with the help of the National Broadband Map', Government Information Quarterly, vol. 32, no. 3, pp. 261-9.

Wikipedia 2015, Western Downs Region, Wikipedia, viewed 10 December 2015, $<$ https://en.wikipedia.org/wiki/Western_Downs_Region>

Willis, S \& Tranter, B 2006, 'Beyond the 'digital divide'Internet diffusion and inequality in Australia', Journal of sociology, vol. 42, no. 1, pp. 43-59.

World Bank 2012, Broadband Strategies Handbook: Chapter 1 Building Broadband, World Bank, <http://broadbandtoolkit.org/Custom/Core/Documents/Broadband\%2 


\section{Appendix 1}

Comparison of wired broadband and wireless broadband services available by cost and data quotas

\begin{tabular}{|c|c|c|c|}
\hline Provider & Data & Cost & \begin{tabular}{|l|} 
Contract terms \\
\end{tabular} \\
\hline \multicolumn{4}{|l|}{ ADSL 2+ } \\
\hline Telstra & 100GB & $\$ 75$ & per month- 24 month contract \\
\hline Telstra & 500GB & $\$ 95$ & per month- 24 month contract \\
\hline Telstra & 1000GB & $\$ 115$ & per month- 24 month contract \\
\hline Optus & Unlimited & $\$ 110$ & per month- 24 month contract \\
\hline TPG -off Net & 50GB & $\$ 49.99$ & per month-6 month contract \\
\hline TPG -off Net & $200 G B$ & $\$ 59.99$ & per month-6 month contract \\
\hline TPG -off Net & 300GB & $\$ 79.99$ & per month-6 month contract \\
\hline TPG -off Net & $500 \mathrm{~GB}$ & $\$ 99.99$ & per month-6 month contract \\
\hline TPG & $50 \mathrm{OBB}$ & $\$ 29.90$ & per month-6 month contract \\
\hline TPG & 150GB & $\$ 39.90$ & per month-6 month contract \\
\hline TPG & $500 \mathrm{~GB}$ & $\$ 49.99$ & per month-6 month contract \\
\hline \multicolumn{4}{|c|}{\begin{tabular}{l|l}
$\$ 59.99$ & per month-6 month contract \\
\end{tabular}} \\
\hline DODO & 10GB & $\$ 49.80$ & per month- 24 month contract \\
\hline DODO & $50 \mathrm{~GB}$ & $\$ 54.90$ & per month- 24 month contract \\
\hline \multicolumn{4}{|c|}{\begin{tabular}{|l|l}
$\$ 59.90$ & per month- 24 month c \\
\end{tabular}} \\
\hline iPrimus & 40GB & $\$ 59.95$ & per month- 24 month contract \\
\hline iPrimus & 100GB & $\$ 69.95$ & per month- 24 month contract \\
\hline iPrimus & 300GB & $\$ 89.95$ & per month- 24 month contract \\
\hline \multicolumn{4}{|c|}{\begin{tabular}{l|l}
$\$ 129.95$ & per $n$ \\
\end{tabular}} \\
\hline iiNet- off net & 100GB & $\$ 79.90$ & per month- 24 month contract \\
\hline iiNet- off net & 300GB & $\$ 89.90$ & per month- 24 month contract \\
\hline iiNet- off net & 500GB & $\$ 119.90$ & per month- 24 month contract \\
\hline iiNet- off net & 1000GB & $\$ 149.90$ & per month- 24 month contract \\
\hline iiNet & $250 G B$ & $\$ 59.90$ & per month- 24 month contract \\
\hline iiNet & 1000GB & $\$ 79.90$ & per month- 24 month contract \\
\hline \multicolumn{4}{|c|}{ Mobile - Post-paid Plan } \\
\hline Telstra & $500 \mathrm{MB}$ & $\$ 35$ & per month - 12 month contract \\
\hline Telstra & $5 \mathrm{~GB}$ & $\$ 50$ & per month - 12 month contract \\
\hline Telstra & $10 \mathrm{~GB}$ & $\$ 60$ & per month - 12 month contract \\
\hline Optus & $1.5 \mathrm{~GB}$ & $\$ 10$ & per month - 24 month contract \\
\hline Optus & $2.5 \mathrm{~GB}$ & $\$ 20$ & per month - 24 month contract \\
\hline Optus & 4GB & $\$ 30$ & per month - 24 month contract \\
\hline Optus & 8GB & $\$ 45$ & per month - 24 month contract \\
\hline Optus & $12 \mathrm{~GB}$ & $\$ 60$ & per month - 24 month contract \\
\hline Optus & $25 \mathrm{~GB}$ & $\$ 90$ & per month - 24 month contract \\
\hline Optus Fixed wireless & $50 G B$ & $\$ 70$ & per month- 24 month contract \\
\hline Vodafone & 4GB & $\$ 20$ & per month - 24 month contract \\
\hline Vodafone & $9 \mathrm{~GB}$ & $\$ 30$ & per month - 24 month contract \\
\hline Vodafone & $13 \mathrm{~GB}$ & $\$ 45$ & per month - 24 month contract \\
\hline Vodafone & $19 \mathrm{~GB}$ & $\$ 60$ & per month - 24 month contract \\
\hline Vodafone & $26 \mathrm{~GB}$ & $\$ 90$ & per month - 24 month contract \\
\hline Vodafone & $51 \mathrm{~GB}$ & $\$ 140$ & per month - 24 month contract \\
\hline
\end{tabular}




\begin{tabular}{|l|l|r|l|}
\hline iPrimus & \multicolumn{1}{|l|}{$\mathrm{GB}$} & $\$ 15$ & per month -24 month contract \\
\hline iPrimus & $2 \mathrm{~GB}$ & $\$ 25$ & per month -24 month contract \\
\hline iPrimus & $6 \mathrm{~GB}$ & $\$ 39$ & per month - 24 month contract \\
\hline & & & \\
\hline Mobile - pre-paid & & & \\
\hline Telstra & $3 \mathrm{~GB}$ & $\$ 30$ & per month- No contract \\
\hline Telstra & $5 \mathrm{~GB}$ & $\$ 50$ & per year- No contract \\
\hline Telstra & $16 \mathrm{~GB}$ & $\$ 140$ & 2 year- No contract \\
\hline Optus & & & \\
\hline Optus & $4 \mathrm{~GB}$ & $\$ 30$ & per month - No contract \\
\hline Optus & $7 \mathrm{~GB}$ & $\$ 50$ & per year- No contract \\
\hline & $22 \mathrm{~GB}$ & $\$ 130$ & per year- No contract \\
\hline TPG & & & \\
\hline TPG & $1.5 \mathrm{~GB}$ & $\$ 19.99$ & per month- No contract \\
\hline TPG & $2 \mathrm{~GB}$ & $\$ 29.99$ & per month- No contract \\
\hline & $5 \mathrm{~GB}$ & $\$ 39.99$ & per month- No contract \\
\hline DODO & & & \\
\hline DODO & $2 \mathrm{~GB}$ & $\$ 17.90$ & per month- No contract \\
\hline DODO & $3 \mathrm{~GB}$ & $\$ 29.90$ & per month- No contract \\
\hline DODO & $6 \mathrm{~GB}$ & $\$ 39.90$ & per month- No contract \\
\hline DODO & $9 \mathrm{~GB}$ & $\$ 49.90$ & per month- No contract \\
\hline & $12 \mathrm{~GB}$ & $\$ 85$ & per month- No contract \\
\hline iiNet & & & \\
\hline iiNet & $2 \mathrm{~GB}$ & $\$ 19.99$ & per month- No contract \\
\hline iiNet & $7 \mathrm{~GB}$ & $\$ 39.99$ & per month- No contract \\
\hline
\end{tabular}

[Note: this figures were captured during the time period 30-05-2016 which may be different other time]

Copyright: (C) 2016 Lane, Tiwari \& Alam. This is an open-access article distributed under the terms of the Creative Commons Attribution-NonCommercial 3.0 Australia License, which permits non-commercial use, distribution, and reproduction in any medium, provided the original author and AJIS are credited.

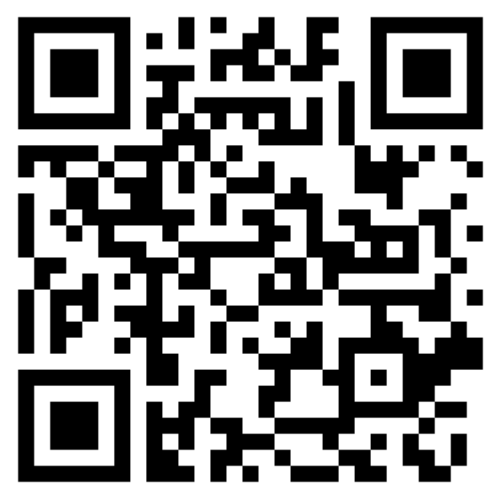

